Archimer, archive institutionnelle de l'Ifremer Vol. 234, Issues 1-4, 18 Dec. 2006, Pages 191-213 http://www.ifremer.fr/docelec/ http://dx.doi.org/10.1016/j.margeo.2006.09.019 (c) 2006 Elsevier

\title{
Vertical grain-size variability within a turbidite levee: Autocyclicity or allocyclicity? A case study from the Rhône neofan, Gulf of Lions, Western Mediterranean
}

\author{
Bernard Dennielou ${ }^{a,{ }^{*}}$, Agnès Huchon ${ }^{a, b}$, Célia Beaudouin ${ }^{c}$ and Serge Berné ${ }^{a}$ \\ alfremer, DRO/GM, BP70, 29280, Plouzané Cedex, France \\ bUMR 6538, Institut Universitaire Européen de la Mer, Place Nicolas Copernic, 29280 Plouzane, \\ France \\ ${ }^{\mathrm{C}}$ Centre de Paléontologie stratigraphique et Paléoécologie (UMR 5565 CNRS), Université Claude \\ Bernard, 27-43, Boulevard du 11 Novembre, 69622 Villeurbanne Cedex, France \\ *: Corresponding author : Bernard.Dennielou@ifremer.fr
}

\begin{abstract}
The fining upward trend commonly described on levees of turbidite systems can be either attributed to changes in the sediment supply (external forcing = allocyclic) or changes in the spillover processes related to the growth of the levee (internal forcing $=$ autocyclic). However the real causes remain speculative and difficult to demonstrate. Knowledge of vertical change in flow velocity (or grain size) in turbidity currents, of the turbidity current's height, as well as the growth rate of a levee are theoretically sufficient to describe the evolution of the grain size of a leveed turbidite sequence deposited by spillover processes.
\end{abstract}

A piston core (MD99-2344) retrieved on the right levee of the Petit-Rhône neofan, sampled an $8.50 \mathrm{~m}$ long turbidite sequence containing more than one hundred turbidite beds and showing a marked fining upward trend. With the help of two profiles describing respectively the vertical velocity [Stacey, $\mathrm{M}$. and Bowen, A.J., 1988b. The vertical structure of turbidity currents and a necessary condition for selfmaintenance, Journal of Geophysical Research, pp. 3543-3553.] and the vertical grain size [Migeon, S., 2000. Dunes géantes et levées sédimentaires en domaine marin profond: approche morphologique, sismique et sédimentologique. PhD Thesis, Université Bordeaux 1, Talence, France, $288 \mathrm{pp}$.] of a turbidity current, and a simple graphical method, we test several hypotheses on the height of the turbidity current and on the grain size at the bottom of the turbidity current and we attempt to reproduce the vertical fining upward trend.

Our results show that the fining upward trend of the turbidite facies can be explained by the aggradation of the turbidite levee and the gradual confinement of the turbidity currents in the channel. This is, therefore, an autocyclical phenomenon. However a high frequency variability of the grain size overprinted on the trend cannot be explained by internal forcing and is believed to be allocyclical, depending on changes to the sediment input. The vertical grain-size profile allows more realistic flow conditions to be determined and shows that the vertical velocity profile does not describe the ability of turbidity current to transport sediment.

This simple graphical method allows a better understanding and quantification of the forcing on turbidite deposits and improves description of the characteristics of the turbidity currents from the grain size of the deposits.

Keywords: turbidite; channel-levee; grain size; autocyclicity; allocyclicity 


\section{Introduction}

Turbidite deposits show very strong variability of their grain size. Within a turbidite sequence the variability is related to hydrodynamic processes in the turbidite current. Failure-induced currents, decelerating with time, deposit the so-called normally graded Bouma sequence (Bouma, 1962). Flood-induced currents, accelerating with time, deposit reversely graded sequences called hyperpycnal deposits (Mulder et al., 2001) or hyperpycnites (Mulder et al., 2002). Channels in deep-sea turbidite systems convey these currents while adjacent levees collect the overflow and commonly records incomplete turbidite sequences (Mulder et al., 2001). Leveed turbidite deposits record the long-term variability of the successive turbidite currents. Their grain size shows orders of variability in relation with external forcing such as continental climate changes, eustatism, (Bouma, 2004) and with internal forcing such as channel avulsion, entrenchment and meandering, levee aggradation, and sediment waves migration (Migeon et al., 2000; Migeon et al., 2001) .

The grain-size of leveed fine-grained turbidite facies is commonly described and interpreted in terms of current overspill processes (Hiscott et al., 1997) and upfan to downfan variability. For instance, in the Amazon fan, Hiscott et al. (1995) and Piper and Deptuck (1995), clearly state that the composition of the sediment overspill and associated hydrodynamic processes are controlled by the height of a turbidite current and the channel depth, and that the grain size of overspilled sediments is negatively correlated to the channel depth. Also, the fining upward trend of the grain size in the levee deposits is interpreted as the imprint of the increase of the channel relief through time related to the levee growth (Manley et al., 1997). . Although the impact of an increasing channel depth and the gradual confinement of the successive turbidite current on leveed turbidite 
facies has never been fully quantified, it is, for instance, though to control the buit-up (in the case in point the decline) of sediment waves fields (Carter et al., 1990; Nakagima and Satoh, 2001).

In this paper we present a $10.77 \mathrm{~m}$ long sediment core collected on the right levee of the Rhône Neofan comprising a $8.5 \mathrm{~m}$ long unit with more than one hundred turbidite sequences, base cut out Bouma sequence (Bouma, 1962), whose median grain size at their base progressively decreases upward. Using a vertical velocity profile and a vertical grain size profiles of turbidite currents from the literature, we will quantify the impact of the aggradation of the levee and the consequent gradual confinement of the successive turbidite currents on the grain-size of the leveed spillover deposits.

\section{Geological setting}

The Gulf of Lions margin, NW Mediterranean (Fig. 1), comprises a $70 \mathrm{~km}$ wide shelf and a slope incised by several major canyons. Its modern architecture is mainly controlled by glacioeustatism (Berné et al., 2001). During high stands, rivers built up sub-aqueous deltas on the inner shelf. During low stands, rivers discharge in the vicinity of, or directly into, the canyons and the deep-sea fans like the Petit-Rhône deep-sea turbidite system (Fig. 1).

The Petit-Rhône Neofan (Figs. 1 and 2) is a lobe-shaped, channelized, sedimentary body formed after the last, westward, avulsion of the Rhône deep-sea turbidite system channel (Droz, 1983; Méar, 1984). It was first described as a chaotic seismic facies (Coutellier, 1985; Droz, 1983; Gaullier et al., 1998; Torres et al., 1997) and consequently interpreted as made of sandy deposits. (Méar and Gensous, 1993). It lies above 2 major sedimentary bodies described by Droz (1983), (1) the levee deposits of the Rhône deep-sea turbidite system (RDTS), and (2) a seismic 
transparent unit of regional extent, interpreted as a debris-flow, the Western Debris-Flow (WDF), (Droz and Bellaiche, 1985) (Fig. 3).

A recent study, based on high resolution seismic data, showed that the neofan actually consists of two units (Bonnel et al., 2005). A lower chaotic, slightly bedded unit, the Neofan Chaotic Unit (NCU), up to $70 \mathrm{~ms}$ two way time (ms twt) thick (50 to $70 \mathrm{~m}$ ), corresponding to the former descriptions, and an upper semi-transparent, slightly bedded unit, the Neofan Transparent Unit (NTU), up to $40 \mathrm{~ms}$ twt thick ( 30 m), overlaying the northwest part of the NCU (Figs. 3 and 4). The NTU has a classical channel-levee shape and is fed by the neofan channel. Bonnel et al. (2005) interpreted the upper unit as the channelized stage of the avulsion, following an early stage of non-channelized deposition of , theHigh Amplitude Reflector Packets (HARPs) also described on the Amazon Deep-sea fan (Flood et al., 1991; Lopez, 2001). The age of the channel avulsion is still in debate. Méar and Gensous (1993) postulated an age of 15 ky but this is contradictory with the age of $15.1 \mathrm{C} 14 \mathrm{ky} \mathrm{BP}$ obtained for the end of spillover deposits on the neofan (Bonnel et al., 2005) and the possible age of 30 cal. ky BP suggested by pollen assemblages at the bottom of core MD99-2344 (Beaudouin et al., 2004).

Bedforms such as giant scours and sediment waves are very common on the neofan area (Bonnel et al., 2005; Droz et al., Submitted; Kenyon et al., 1995). Giant sediment waves (wave length $\sim 2 \mathrm{~km}$ ) are located close to the channel avulsion point (Bonnel et al., 2005 and Fig. 2). Although no detailed study of the sediment waves exists, their size, orientation and cross-cut by the neochannel suggest that they are related to spillover processes before the channel avulsion. Undulating seafloor (not visible on the bathymetry) and internal reflectors, suggestive of smaller sediment waves (wave length $\sim 250 \mathrm{~m}$, height $<1 \mathrm{~m}$ ), are clearly observed on the chirp profile at the core location (Fig. 4). The upslope migration of the crest suggests a generation related to 
turbidity current overspill and the small wave-length and amplitude is similar to what can be observed also for distal location on the Monterey and Hueneme fans (Normark et al., 2002). Although marked grain size variability related to sediment waves migration have been reported (Migeon et al., 2004; Migeon et al., 2001; Wynn and Stow, 2002), those were reported for higher wavelength and amplitude sediment waves. We assume that small wave length and amplitude generates also smaller changes in the grain size. In addition, the small distance of migration recorded in the sediment core (26 m for $10 \mathrm{~m}$ aggradation) suggests small grain size changes with regard to the wave length.

The field of giant scours is located at the distal part of the neofan (Bonnel et al., 2005 and Fig. 2) and is adjacent to the core location. The origin and age of these scours are still not understood. Bonnel et al. (2005) suggest that they might be a relict from an ancient position of the neochannel mouth but the lack of infill as observed on sub-bottom profiles (Kenyon et al., 1995) and on piston cores (Dennielou et al., 2003) suggests a very recent (Holocene) activity. As the sediment core is located upstream the scour field, it is possible to postulate that these bedforms are of small influence on the turbidite spillover processes and deposits.

The sediment core MD99-2344 (Latitude N 4159.44', Longitude E450.14', water depth 2326 m) was retrieved in the NTU (Fig. 3 and Fig. 4) on the right levee (Fig. 2). It sampled $37 \%$ of the NTU (Fig. 4), which is $39 \mathrm{~ms}$ twt thick at the core location $(\sim 29 \mathrm{~m}$ assuming a reference sound velocity on sediments of $1.5 \mathrm{~km} \cdot \mathrm{s}^{-1}$ ). It is located at $\sim 1.5 \mathrm{~km}$ from the crest of the levee, where this unit reaches its maximum thickness (52 ms twtt, approximately $39 \mathrm{~m}$ ); this value of $39 \mathrm{~m}$ corresponds also to the depth of the channel as it does not incise the chaotic unit beneath the levee (Fig. 3). 
Since 15.1 kyrs BP (radiocarbon age) the area collected only hemipelagic sedimentation and occasional sandy inputs from the adjacent canyon network (Bonnel et al., 2005).

\section{Material and data}

\subsection{Analyses}

$X$-ray images were acquired with the Scopix system (Migeon et al., 1999). Processing of the images is partly based on Lofi and Weber (2001).

Grain-size analyses were performed with a Coulter LS130 laser microgranulometer. In order to avoid the mixing of sediments from different beds, samples were carefully sampled, particularly within the silt laminae and at the boundary between silt layers and mud layers,. Clay samples were exposed to gentle ultrasounds until suspension was complete.

Carbonate contents were measured using an automatic calcimeter developed by University Bordeaux I and Aquitaine Technologie Innovation (ATI). The analysis is based on the measurement of the carbone dioxide overpressure generated by the dissolution of the carbonates within $4 \mathrm{~N} \mathrm{HCl}$ acid. Calibration is based on the analysis of a pure carbonate sample every 19 sediment samples. The accuracy of measurements is $\pm 1 \%$.

Pollen grains and dinocysts were extracted with a light chemical treatment using cold acids [ $\mathrm{HCl}$ (33\%) and $\mathrm{HF}(70 \%)$ ] and $\mathrm{ZnCl} 2$ in order to preserve all dinocysts [Turon, 1984 \#1915]. Abundance of each pollen species was calculated when a minimum of 150 pollen grains (Pinus excluded) was counted. Dinocyst, abundance was calculated on a minimum of 100 individuals. Pollen grain and dinocyst concentrations were calculated using the Cour method (Cour, 1974).

\subsection{Sediment facies, palynology and chronology}




\subsubsection{Facies description}

From the bottom to $340 \mathrm{~cm}$ the sediment is composed of alternating silty and clayey beds. The lithology of the silt beds consists of detrital quartz and calcite, few large calcareous nannofossils and some heavy minerals. The lithology of the mud beds consists of clay, with very fine $(<4 \mu \mathrm{m})$ detrital quartz and calcite, few silty detrital quartz and calcite, and few calcareous nannofossils. Four facies are distinguished on the base of the structure (visual observation and X-ray photographs), grain size analyses.

Facies 1 (Fig. 6) is composed of $\sim 3 \mathrm{~cm}$ thick coarse silt beds, overlain by $\sim 1 \mathrm{~cm}$ thick silty clay beds. The average silt and silty clay bed thickness ratio is about 3.5. The silty beds have a sharpundulating or erosive basal contact and are normally graded with a grain-size median ranging from a very maximum of $75 \mu \mathrm{m}$ (very fine sand) to $40 \mu \mathrm{m}$. They display horizontal and obliquecross laminations (Fig. 10). The silty clay beds contain colour laminations and some silt laminae. The transition between the silty beds to the silty clay beds is gradational consisting either of mud laminae, lenticular silt laminae or irregular silt laminae.

Facies 2 (Fig. 7) is composed of $\sim 5 \mathrm{~cm}$ thick coarse silt beds, overlain by $\sim 3 \mathrm{~cm}$ thick silty clay beds. The average silt and silty clay bed thickness ratio is about 1.3 . The silt beds have a sharply undulating or erosive basal contact and are normally graded with a grain-size median ranging from $60 \mu \mathrm{m}$ to $35 \mu \mathrm{m}$. They display horizontal and oblique-cross laminations (Fig.10). The top of the silty clay beds displays color banding and is homogeneous on the X-ray photograph (i-e no density variations). The transition between the silty beds and the silty clay beds is gradational or sharp, consisting of millimetric, continuous to discontinuous, silt laminae.

Facies 3 (Fig. 8) is composed of $\sim 1 \mathrm{~cm}$ thick medium silt beds, overlain by 4 to $8 \mathrm{~cm}$ thick, laminated, silty clay. The average silt and silty clay bed thickness ratio is in about 0.25 . The silty 
beds have a sharp or erosional basal contact. They can be normally graded with a grain-size median ranging from $35 \mu \mathrm{m}$ to $15 \mu \mathrm{m}$. The thickest silty beds display cross laminations, while others are too thin for displaying any sedimentary structure (Fig. 10). The silty clay beds show very abundant silt laminae with a median of about $15 \mu \mathrm{m}$. The contacts between the silt beds and the silty clay beds are sharp. Several order of laminae are visible, from millimetric, with a median of $20 \mu \mathrm{m}$, to inframillimetric.

Facies 4 (Fig. 10) is composed of mud with medium silt laminae. Several orders of laminae are visible, from millimetric with a grain-size median of $20 \mu \mathrm{m}$ to infra-millimetric. This facies does not allow identification single event deposits (Fig. 9).

From $340 \mathrm{~cm}$ to $232 \mathrm{~cm}$ the sediment is dominantly composed of clay and silts (quartz and detrital carbonates) but the marine biological content (dynocysts) tends to increase, witnessing and increase of the pelagic input. Silt laminae are abundant and suggest turbiditic depositional processes.

From $232 \mathrm{~cm}$ to the top the sediment contains a significant pelagic contribution (foraminifera and calcareous nannoplancton). The carbonate content ranges from $34 \%$ to $51 \%$ and the sediment can be interpreted as foraminifera and calcareous nannoplancton silty clay according to the classification from (Flood et al., 1995). Up to seven centimetric silty to sandy beds whose origin is discussed in Bonnel et al. (2005) are intercalated in this interval.

\subsubsection{Sequence description and interpretation}

From the bottom to $232 \mathrm{~cm}$ alternating silty beds and clayey beds exhibit a strong grain-size variability (Fig. 5). The most important variability is observed within the silty clay/silt couplets where the median typically ranges between $60 \mu \mathrm{m}$ (coarse silts) at the bottom of the silty bed, to 
5-10 $\mu \mathrm{m}$ within the silty-clay bed (Fig. 6). Silty beds are commonly positively graded (Figs. 6 and 7), display parallel and cross stratifications (Fig. 10) and thin upward (Fig. 5). Clayey beds thicken upward (Fig. 5) and contain abundant silty laminae. Besides this very pronounced variability, a very distinct, fining-upward trend of the median grain size at the bottom of the silty beds is observed (Fig. 5). The median at the bottom of the silty beds range from $85 \mu \mathrm{m}$, at the bottom of the core, to $20 \mu \mathrm{m}$ at $348 \mathrm{~cm}$ (Fig. 5). The fining-upward of the median is well represented by three linear trends. From the bottom to $937 \mathrm{~cm}$ the fining-up is about -0.12 $\mu \mathrm{m} . \mathrm{cm}^{-1}$, from $937 \mathrm{~cm}$ to $615 \mathrm{~cm}$ it is about only $-0.03 \mu \mathrm{m} . \mathrm{cm}^{-1}$ and from $615 \mathrm{~cm}$ to $348 \mathrm{~cm}$ it is about $-0.07 \mu \mathrm{m} . \mathrm{cm}^{-1}$. These facies are interpreted as silt-mud turbidites (Stow and Piper, 1984), deposited from the overflow of turbidite currents from the neofan channel. Facies 1 to 4 are interpreted as fine-grained turbidites. According to the nomenclature of Bouma (1962) and Stow \& Piper (1984), facies 1 is made of divisions C, E1 $\left(\mathrm{T}_{0}\right.$ to $\left.\mathrm{T}_{2}\right)$ and few E3, facies 2 is made of divisions $\mathrm{C}$, E1 $\left(\mathrm{T}_{2}\right.$ to $\left.\mathrm{T}_{3}\right)$ and $\mathrm{E} 3$, facies 3 is made of divisions $\mathrm{C}, \mathrm{E} 1\left(\mathrm{~T}_{3}\right)$ and $\mathrm{E} 3$, facies 4 is made divisions E1 $\left(\mathrm{T}_{3}\right)$ and E3. The ideal sequence as defined by Piper and Stow (1991) is never fully observed, and the division D (graded, fine, parallel-laminated silts) is always absent.

From $232 \mathrm{~cm}$ to the top the hemipelagic facies witnesses the sediment starvation of the neofan (Bonnel et al., 2005). Silty to sandy beds are interpreted as deposits from instabilities at the shelf break (Bonnel et al., 2005) conveyed into the deep basin through the Sète canyon network (Droz et al., 2001) and possible temporary storage and flush at the canyon heads (Gaudin et al., this issue).

\subsubsection{Palynology}


The palynological study focused on the abundance of dinocysts and pollen grains and is fully detailed in Beaudouin et al. (2004). In the oceans, the main source for pollens comes from the rivers, which is 400 times higher than the input from the winds (Cambon et al., 1997). As they float on the sea, pollen grains progressively sink into the sea bottom, their residency time within the water column depending on the taxa (Beaudouin et al., 2005). Therefore, pollen is scarce on the outer shelf and the deep basin. In the upper unit dinocysts dominate the palynofacies (dynocysts + pollen grains) (Fig. 5). Their relative abundance range from $50 \%$ to $20 \%$ in the hemipelagic mud to less than $10 \%$ in the ooze and correspond to a dominantly marine environment. On the other hand, the low abundance of pollen grains witnesses the low fluvial input, in agreement with the remote position of the Rhône river mouth. In the lower unit pollens dominate the assemblage. Their relative abundance is $>90 \%$ from the bottom to $340 \mathrm{~cm}$ and range from $80 \%$ to $90 \%$ from $340 \mathrm{~cm}$ to $232 \mathrm{~cm}$ (Fig. 5). It shows a fluvial origin for the lower unit, which, according to the chronology, confirms the fluvial origin of the turbidite facies, in relation with the connection of the Rhône River with the deep-sea fan during the last glacial sea level low stand.

\subsubsection{Stratigraphic framework}

Five AMS radiocarbon were carried out on tests of Globigerina bulloides (Table 1). Foraminifera are abundant in the upper unit, while they are almost absent in the lower unit. The conversion into corrected (calendar) ages was made with Calib 4.3 and the INTCAL98 marine dataset (Stuiver et al., 1998), no deviation from global reservoir age has been used. Ages in the upper unit give a deglacial age to Holocene age for the Foraminifera and calcareous nannoplancton silty-clay. The limit between the turbiditic sequence and the hemipelagic sequence is dated at $15.11 \pm 40 \mathrm{C}-14 \mathrm{ky}$ 
BP ( 17.8 cal. ky BP) and follows by about 2-3 ky the beginning of the deglacial sea level rise, estimated at about 20-21 cal. ky BP ky BP (Lambeck et al., 2002). These ages confirm the relationship of the sequences with sea-level.

Pollen associations in the turbiditic sequence allow us to postulate an age of $18.6 \mathrm{ky}$ BP (C-14 scale) at a depth of $7.06 \mathrm{~m}$ (Beaudouin et al., 2004).

These ages are in contradiction with the age of $15 \mathrm{ky}$ BP postulated for the onset of the neofan by Méar and Gensous (1993). However, turbidite facies are commonly characterized by accumulation rates of several meters per ky (Migeon et al., 2004; Showers et al., 1997) therefore, the age at the bottom of the core may be no older than about 19 cal. ky BP and rate of deposition of the turbiditic bed may more than 1 every 10 year.

\section{Methods}

In order to determine whether the grain size variability in the turbiditic sequence is controlled by external and/or internal forcing it is necessary to quantify the potential impact of these factors on the deposited grain size. Because we have a good knowledge of the geometry of the channellevee at the core location, we can quantify the relationships between the grain size in a turbidite sequence $(\sqrt{\times})$, the channel-levee height $(C L H)$ and resulting confinement of turbidite currents (internal feedback ) and a turbidite current thickness (TCT) (external forcing).

In order to establish a relationship between a turbidite facies and a turbidity current, we postulate that the grain size at the base of a turbidite bed from core MD99-2344 witnesses the grain size in the corresponding turbidity current, at a height corresponding to the $C L H$ at the time of the deposition of the bed (Fig. 11). A vertical velocity profile of turbidite current is given by Stacey and Bowen (1988b) (Fig. 12), A vertical grain size profile in a turbidite current is given by 
Migeon (2000) (Fig. 13) and also by Pirmez et al. (2003), this later will not be used, but both profiles show a marked concentration of sand at the bottom of the turbidity currents. The relationship between the vertical profiles and the geometry of the channel-levee is shown on Figure 11. It should be noted that our core is not located at the top of the levee, therefore the present aggradation at the core location $(l=29 \mathrm{~m})$ ) is less important than the aggradation at the top of the levee $(L=39 \mathrm{~m})$. The ratio between these aggradations $\left(\frac{L}{l}\right)$, based on seismic data (Fig. 4) is estimated at 1.34.

\subsection{The relationship between current velocity and grain size}

In order to compare the profiles of Stacey and Bowen (1988b) and Migeon (2000), and to connect the grain sizes in core MD99-2344 with the velocity profile from Stacey and Bowen (1988b), we must use a relationship between the grain size and the current velocity. An equation for the current velocity $(u)$ is given by equation (1) from Bowen et al. (1984) and Klaucke et al. (1997), where $u_{*}$ is friction velocity and $C_{f}$ is the drag coefficient. In our study, according to the slope of $0.2^{\circ}$ in the neofan channel (Torres et al., 1997) and to Stacey and Bowen (1988a, Figure 6), the drag coefficient $\left(C_{f}\right)$ is equal to 0.004 .

$$
u^{2}=\frac{u_{*}^{2}}{C_{f}}
$$

Bowen et al. (1984) suggest that the friction velocity $\left(u_{*}\right)$ can be estimated with equation (2) from the settling velocity $\left(w_{s}\right)$ and a factor $(k)$ depending on flow conditions for transport. For a suspended load, like in a turbidite current, we have $k=1.25$. 


$$
u_{*}=k w_{s}(2)
$$

The settling velocity $\left(w_{s}\right)$ is calculated using the Stockes' law (3) for laminar fluid conditions, where $D$ is the grain size of a particle, $\rho_{g}=2650 \mathrm{~kg} \cdot \mathrm{m}^{-3}$ for quartz is the density of the particle, $\rho_{f}=1024 \mathrm{~kg} \cdot \mathrm{m}^{-3}$ is the density of sea water, $g=9.81 \mathrm{~m} \cdot \mathrm{s}^{-2}$ is acceleration due to gravity and $\mu=$ $1.202 \times 10^{-3} \mathrm{PI}\left(\mathrm{kg} \cdot \mathrm{m}^{-1} \cdot \mathrm{s}^{-1}\right)$ is the dynamic viscosity of the water at $13^{\circ} \mathrm{C}$, the average temperature at $2000 \mathrm{~m}$ deep in the study area (from LEVITUS).

$$
w_{s}=\frac{D^{2}\left(\rho_{g}-\rho_{f}\right) g}{18 \mu}
$$

Therefore, the current velocity $(u)$ can be calculated with equation (4) as a function of the grain size $(D)$ and the grain size can be calculated with equation (5) as a function of the velocity. The grain size at the base of the turbidite sequences will be expressed as the median of the grain size distribution (Fig. 5).

$$
u=\frac{k\left(\frac{D^{2}\left(\rho_{g}-\rho_{f}\right) g}{18 \mu}\right)}{\sqrt{C_{f}}}
$$

$$
D=\left(\frac{u 18 \mu \sqrt{C_{f}}}{k g\left(\rho_{g}-\rho_{f}\right)}\right)^{1 / 2}
$$


For non-laminar conditions the Stokes' law is not valid and the settling velocity must be calculated with the Heywood tables (Holdich, 2002). In our study, Heywood tables must be used for particles larger than $70 \mu \mathrm{m}$.

\subsection{Vertical velocity and grain size profiles}

Stacey and Bowen (1988b) have developed a 1D model describing the properties of a turbidite current in the vertical distribution. When running their model for turbidite current composed of two grain sizes (10\% fine sand and $90 \%$ fine silt), they show that the vertical velocity distribution quickly reaches an equilibrium. The vertical velocity profile shows a big-bellied shape (Fig. 12, left) that is not significantly influenced by the grain size. Such a shape is also predicted by a 2D model of Felix (2002) and discussed in a review article by Kneller and Buckee (2000). According to these authors, the height of the velocity maximum is controlled by the ratio of the drag forces at the upper and lower boundaries and, in many experimental currents, is found to occur at 0.20.3 of the height of the current. The corresponding grain size vertical profile (Fig. 12, right), calculated with equation (5) is shown for a comparison.

A vertical grain size was drawn by Migeon (2000) on the Var turbidite system (Western Mediterranean) (Fig. 13, right). This author collected several cores along the top of the Var Turbidite Levee at several water depths and channel-levee heights. For each core and for equal periods of time, he calculated an average of the median grain size of the base (coarse sediment) of the turbidite sequences. Postulating that (1) the levee deposits are turbidite overspill (2) the levee aggradation is autocyclic, $\mathrm{i}$-e that the averaged grain-size along the levee is controlled by the $C L H$, the plot of the median grain-size versus the CLH is assumed to represent vertical grain-size distribution of the turbidite currents.. We will assume that the shape of the profile do 
not depend on the grain size of the sediment load. The corresponding velocity vertical profile (Fig. 13, left), calculated with equation (4) is shown for a comparison.

\subsection{Calculation of the relationship between the grain size ( $G S$ ) (or velocity), the channel- levee height $(C L H)$ and the turbidity current thickness (TCT).}

The vertical profiles are normalised (i.e. the shape is constant, regardless of velocity, grain size or current thicknesses are) and they need to be calibrated. Values for a grain size (or converted equivalent in velocity) are given by the median at the base of the turbidite beds. Values for the corresponding height in the current $(C L H 1,=$ channel-levee height at the deposition of the turbidite bed) are given with equation (6) by the present channel-levee height $(C L H 2=39 \mathrm{~m})$ and the depth in core $(D C 1)$ of the base of the turbidite bed corrected from difference in the aggradation at the core location: $\left.\frac{L}{l}=1.34\right)$ (Fig. 11)

$$
C L H 1=C L H 2-\left(\frac{L}{l} D C 1\right)(6)
$$

Next, we need to calibrate at least one axis. In order to estimate the $T C T$, we will test several hypotheses on the grain size at the bottom of the turbidite current (channel-bottom grain size $=$ $C B G S$ ). Therefore, according to the measured median from a turbidite sequence $(G S)$ and to the corresponding $C L H$ calculated with equation (6) we can graphically determine the TCT (Fig. 12 and Fig. 13). Also, following the same method, a grain size ( $G S$ ) for the base of a turbidite bed can be graphically determine for a given $T C T$ and $C B G S$. 
In order to optimize the graphical calculations, we propose a simplification that allows the determination of equations and the use of a simple Excel $^{\mathrm{TM}}$ spreadsheet. Figure 12 and Figure 13 show that for $C B G S$ values higher than the $G S$ measured at the bottom of the tubidite beds, only the upper part of the profiles are used for the graphical determinations. Thus, this part of the profiles has a simple shape that fits properly with a second order polynomial and a logarithmic curve, on Figure 12 (left) and Figure 13 (right) respectively. The curve fit has been calculated for several $C B G S$, from $70 \mu \mathrm{m}$ to $400 \mu \mathrm{m}$ (Table 2 and 3); each corresponds with a set of coefficients ( $\mathrm{a}, \mathrm{b}$ and $\mathrm{c}$ for the polynomial equation, and a and $\mathrm{b}$ for the logarithmic equation). Equations $(7,9)$ of curves fit for the calculation of $T C T$ 's from the profiles of Stacey and Bowen (1988b) and Migeon (2000), respectively, are given. Equation (8) of the curve fit for the calculation of velocities (and $G S$ 's through equation (5) or using Heywood tables) is given for the profile of Stacey and Bowen (1988b)(8is given. Equation (10) of the curve fit for the calculation of $G S$ 's from the profile of Migeon (2000) is given.

$$
\begin{aligned}
& T C T=\frac{341 C L H}{a u^{2}+b u+c}(7), \text { where } u \text { is the velocity } \\
& a x^{2}+b x+c=\text { velocity, with } x=\frac{341 C L H}{T C T}(8) \\
& T C T=\frac{500 C L H}{a \ln (G S)+b}(9) \\
& a e^{(-b x)}=G S, \text { with } x=\frac{500 C L H}{T C T}(10)
\end{aligned}
$$




\section{Results}

\subsection{Turbidity current thicknesses ( TCT s)}

The $T C T \mathrm{~s}$, shown in Figure 14 and Figure 16, were calculated for $C B G S$ of $70 \mu \mathrm{m}, 90 \mu \mathrm{m}, 120$ $\mu \mathrm{m}, 150 \mu \mathrm{m}, 200 \mu \mathrm{m}, 300 \mu \mathrm{m}$. A value of $400 \mu \mathrm{m}$ for $C B G S$ was only used for the profile from Migeon (2000). The method of calculation implies the $T C T$ s to be necessarily higher than the Channel-Levee Height ( $C L H$ ), as we interpreted the turbidite facies as overflow deposits. TCT s are always negatively correlated to the $C B G S$, which is consistent with the method, and shows that the coarsest turbidity currents are the thinnest (Fig. 16). The variability of the $T C T \mathrm{~s}$ is important for $C B G S$ below $150 \mu \mathrm{m}$ and low for coarser values.

TCT s from profile of Stacey and Bowen (1988b)(Fig. 14): TCT s range from $25.1 \mathrm{~m}$ to $73.5 \mathrm{~m}$. For most of the $C B G S, T C T$ s are only slightly higher than the $C L H$ and, therefore, are strongly positively correlated to the $C L H$ with low variability around the trend. A $C B G S$ of $70 \mu \mathrm{m}$ is needed to obtain $T C T \mathrm{~s}$ not correlated to the $C L H, T C T \mathrm{~s}$ are constant at $38 \mathrm{~m}$ for $C L H \mathrm{~s}$ between $24.6 \mathrm{~m}$ (the bottom of the core) and $31.1 \mathrm{~m}$, while they remain correlated to the $C L H$ between $C L H \mathrm{~s}$ of $31.1 \mathrm{~m}$ and $34.4 \mathrm{~m}$.

The amplitude of the variations is high, about $20 \mathrm{~m}$, which represents $53 \%$ of the average. The variability over the trends are positively correlated to the median grain size of the turbidite beds $\left(r^{2}\right.$ ranging between 0.32 and 0.39$)$.

The constant increase of $T C T$, proportional to the $C L H$, observed for coarse $C B G S$ is rather unrealistic. A constant $C L H$, modulated by a $20 \mathrm{~m}$ amplitude, obtained for a $C B G S$ of $70 \mu \mathrm{m}$ is 
realistic. A $C B G S$ of $70 \mu \mathrm{m}$ implies that the maximum grain size within the turbidite current is only $95 \mu \mathrm{m}$.

TCT s from profile of Migeon (2000) (Fig. 15): The TCTs range from $27.9 \mathrm{~m}$ to a maximum of $1704 \mathrm{~m}$. Nevertheless, the average maximum TCTs are around $400 \mathrm{~m}$. They display a constant trend of $87 \mathrm{~m}, 72 \mathrm{~m}$ and $58 \mathrm{~m}$ for $C B G S$ of $120 \mu \mathrm{m}, 150 \mu \mathrm{m}$ and $200 \mu \mathrm{m}$, respectively, with respective average amplitudes of $59 \%, 51 \%$ and $43 \%$ of the trend. The variability over the trends is positively correlated to the grain size of the turbidite beds ( $\mathrm{r}^{2}$ ranging between 0.29 and 0.42 ). For $C B G S$ between $400 \mu \mathrm{m}$ and $300 \mu \mathrm{m}$ and $C L H$ between $24.6 \mathrm{~m}$ and $31.1 \mathrm{~m}$ the trend is slightly positively correlated to the $C L H$. For $C L H$ between $31.1 \mathrm{~m}$ and $34.4 \mathrm{~m}$ the trend is negatively correlated to the $C L H$. For this interval, for $C B G S$ of $400 \mu \mathrm{m}$ and $300 \mu \mathrm{m}$ few $T C T \mathrm{~s}$ are lower than the $C L H$. They correspond to turbidite beds with very low medians. They are located on the lower, asymptotic part, of the fitted curves and, therefore, are not significant.

Because of the shape of the vertical grain size distribution (Figs 12 and 13) the TCT s are much higher than for Stacey and not correlated to the $C L H$. The results obtained for $C B G S$ coarser than $120 \mu \mathrm{m}$ imply a strong vertical positive grain size grading within the turbidity current.

\subsection{Grain Size $(G S)$}

The theoretical grain size of levee deposits, according to the $C L H$, were calculated for the same as for the $T C T$ calculations, and for $T C T$ s of $30 \mathrm{~m}, 35 \mathrm{~m}, 40 \mathrm{~m}$, and $150 \mathrm{~m}$ for profile of Stacey and Bowen (1988a), and TCT s of $38 \mathrm{~m}, 58 \mathrm{~m}, 115 \mathrm{~m}$ and $500 \mathrm{~m}$ for profile of Migeon (2000). These $T C T \mathrm{~s}$ were chosen to span and to illustrate the most significant results. According to 
equations (8) and (10), the grain size shows a second order polynomial fining upward for Stacey and Bowen's (1988b) profile, and an exponential fining upward for Migeon's (2000) profile.

Grain size from profile of Stacey and Bowen (1988b) (Fig. 17): The coarsest deposits are obtained for the coarsest $C B G S$ and the thickest turbidity currents. For $T C T$ s between $70 \mathrm{~m}$ and $150 \mathrm{~m}$ the deposits are coarser than the $C B G S$, as it is predictable from the big-bellied shape of the grain size profile. For thicker turbidity currents $(>150 \mathrm{~m})$ the $G S$ should decrease to reach the value of the $C B G S$ but it is not observed, as our equations do not include the bottom of the grain size profile. The $G S$ always shows a fining upward. Figure 17a shows that turbidity currents cannot deposit sediments on the levee when the $C L H$ reaches the $T C T$. This is in agreement with the non- asymptoptic top of the grain size profile (Fig. 12). Turbidity currents thicker than $34.4 \mathrm{~m}$ are able to spill sediments over the levee as they always remain above the $C L H$. Good representations of the median and the fining upward measured on the sediment core are calculated for a $T C T$ of $35 \mathrm{~m}$ with $C B G S \mathrm{~s}$ of $70 \mu \mathrm{m}$ and $90 \mu \mathrm{m}$ (Fig. 17b) and for a $T C T$ of 40 m with a $C B G S$ of $70 \mu \mathrm{m}$ (Fig. 17c). Combinations of coarser $C B G S \mathrm{~s}$ with $T C T \mathrm{~s}$ thicker than 50 $\mathrm{m}$ always provide $G S \mathrm{~s}$ coarser than measured on the sediment core. A significant fining upward of the GS is always obtained for TCT s between $35 \mathrm{~m}$ and $50 \mathrm{~m}$, thicker $T C T$ s provide an almost constant GS (Fig. 17d).

Grain size from Migeon's profile (2000) (Fig. 18): On the contrary to the previous profile, even TCT s lower than the $C L H$ predict sediment spillover. This is a consequence of the asymptotic shape of the profile on the vertical axis (Fig. 13) and that the curve fit does not describe properly the grain size distribution at the top of a turbidity current. As for the previous 
profile, the coarsest deposits are obtained for the coarsest $C B G S$ and the thickest turbidity currents. The $G S$ always shows a strong fining upward for $T C T$ s lower than $200 \mathrm{~m}$. A good representation of the median and the fining upward measured on the sediment core is only provided by a $T C T$ of $38 \mathrm{~m}$ with a $C B G S$ of $400 \mu \mathrm{m}$ (Fig. 18a). Thicker turbidity currents fail to predict the whole trend of the median, and especially the abrupt drop in the trend at $5.89 \mathrm{~m}$ deep in the core (corresponding to a $C L H$ of $\sim 31 \mathrm{~m}$ ). A good representation of the fining upward trend from the bottom of the core to $5.89 \mathrm{~m}$ is provided by a $T C T$ of $58 \mathrm{~m}$ with a $C B G S$ of $200 \mu \mathrm{m}$, and TCT of $115 \mathrm{~m}$ with $C B G S \mathrm{~s}$ between $70 \mu \mathrm{m}$ and $120 \mu \mathrm{m}$. TCT s over $500 \mathrm{~m}$ provide $G S \mathrm{~s}$ coarser than measured on the sediment core and a weak fining upward trend.

\section{Discussion}

\subsection{Calculated turbidity current thicknesses (TCT s)}

The top of a turbidiry current is not a sharp limit (like the bottom) but a progressive upward dilution of the turbidite plume. Nevertheless, it can be defined as a threshold where the concentration of the particle becomes negligible. It is also defined as the limit between a suspension layer and clear water (Salaheldin et al., 2000). Our calculations give a wide range of thickness for the turbidity currents, from a few tens of metres to several hundreds of metres. High thicknesses are in the same range as those described by several other authors (Felix, 2002; Salaheldin et al., 2000; Stacey and Bowen, 1988b; Stow and Bowen, 1980) who predicted thicknesses over $400 \mathrm{~m}$. They are also in agreement with some turbidite systems like, for instance, the Var deep-sea fan (Savoye et al., 1993) and the Zaire deep-sea fan (Savoye et al., 2000), whose channel depth reaches more than 300 m. Moreover, on the Petit-Rhône deep-sea fan, downstream of avulsion point of the neochannel, Torres et al. (1997) described channel-levee 
heights of $120 \mathrm{~m}$ associated with leveed turbidite facies and, thus, demonstrated the occurrence of more than $120 \mathrm{~m}$ thick turbidity currents $60 \mathrm{~km}$ upstream of our core MD99-2344.

Our calculations also show that $T C T$ s are negatively correlated to the $C B G S$ and, therefore, to the coarseness of the turbidity currents (Fig. 16). This feature is also postulated by Bowen et (1984) or Stow and Bowen (1980), the latter showing a quasi-exponential drop of the current thickness according to the modal grain size, similar to what is shown in Fig. 16. On the other hand, Felix (2002) and Salaheldin et al. (2000) demonstrated turbidite current thicknesses positively correlated to the grain size. However, Felix (2002) also pointed out that coarse currents have a vertical velocity and concentration gradient stronger than for finer-grained currents, meaning that most of the sediment is actually concentrated near the channel bottom and, thus, not easily spilled over a levee. This view is also similar to the two layer model used by Mulder et al. (1997). In that sense and according to our calculations, coarse-grained currents are thinner than fine-grained currents.

Despite these considerations, the velocity profile from Stacey and Bowen (1988b) fails in the assessment of $T C T \mathrm{~s}$ for two reasons. Firstly, for $C B G S \mathrm{~s}$ higher than $90 \mu \mathrm{m}, T C T \mathrm{~s}$ are positively correlated to the $C L H$. Such a trend for TCT s would imply a control by an external forcing such as the deglacial sea-level rise and a gradual disconnection of the Petit-Rhône River from its canyon, but this forcing might also imply gradually less voluminous turbidite currents and, therefore gradually decreasing $T C T$ s. In the hypothesis that the increase of the channel depth is controlled by the levee aggradation, such positive good correlation of the channel depth (internal forcing) and TCTs (external forcing) is a very improbable coincidence. In the hypothesis that channel depth is also controlled by erosion, the positive correlation with TCT may be realistic and the whole neofan turbidite system would be under allocyclic control. Secondly, the trend of 
TCT s is almost constant for CBGS s lower than $90 \mu \mathrm{m}$. This is a satisfactory and realistic behaviour, as does not correlate to the $C L H$. However, these currents imply a small vertical gradient for the velocity and the grain size (almost the same grain size at the bottom of the current and at the top), which is in contradiction with the models of Felix (2002) and Mulder et al. (1997).

On the other hand, the grain size profile from Migeon (2000) gives TCT s not correlated to the $C L H$ and seems more adapted for our purpose. Also, the values of TCT s and CBGS imply a strong vertical grain size gradient, which is consistent with models from Felix (2002) and Mulder et al. (1997). For $C B G S$ of $200 \mu \mathrm{m}$ the constant trend of TCT s implies constant volumes and compositions of the turbidite currents that could, for instance, have occurred during last maximum low stand of sea level that could be characterized by frequent (annual?) turbidity currents during a very short period of time. For $C B G S \mathrm{~s}$ greater than $200 \mu \mathrm{m}$ the slight increase in $T C T$ s could relate to an increase in the activity of the Rhône river, while for $C B G S$ s lower than $200 \mu \mathrm{m}$ the decreasing trend could be related to the deglacial sea level rise and a gradual starvation of the Rhône Deep-sea fan, related to a gradual disconnection of the river from its canyon. For $C L H>31.1 \mathrm{~m}$ the $T C T$ s behave differently and start to decrease. This behaviour suggests an external forcing. The high amplitude of the variability of TCTs over the trends is quite satisfactory as it respects the variability of the median in the sediment core, which is believed to reflect the true variability of the volume and characteristics of turbidity currents.

TCT s with a constant trend (no external forcing) and a strong vertical grain size gradient range between $\sim 30 \mathrm{~m}$ and $\sim 90 \mathrm{~m}$. One could argue that such low TCT s may not be realistic, as they would not enable upstream sediment overspill, where the $C L H$ is $120 \mathrm{~m}$ and where recent (11 ka) turbidite facies have been described by Torres et al. (1997). Nevertheless, we believe that 
they are coherent with the distal position of the study area which may experience rather depleted turbidity currents, enriched with sand and, therefore, rather thin. Moreover, the shape of the channel near the sediment core is narrower ( $\mathrm{V}$-shaped, heigth $34 \mathrm{~m}$, maximum width $500 \mathrm{~m}$ ) than the channel upstream of the avulsion (U-shaped, height $120 \mathrm{~m}$, bottom width $750 \mathrm{~m}$, top width $1250 \mathrm{~m}$ ), suggesting a possible acceleration and consequent flattening of the current. The slope value is almost identical at both locations (Torres et al., 1997).

\subsection{Calculated grain sizes of turbidite beds}

The calculted grain sizes for the turbidite beds support the same comments as for the TCTs. Nevertheless, they are a convenient way to visualise the impact of the levee aggradation on the grain size of the levee deposits. The satisfactory fit of our calculations with the grain size in the sediment core, determined with the profile of Stacey and Bowen (1988b) implies turbidity currents with an unlikely rather constant vertical velocity or grain size distribution. On the other hand, the satisfactory fit found with the grain size profile of Migeon (2000) implies turbidity currents with a likely coarse-bottomed base and a strong vertical grain size gradient. Again, the upper part of the turbidite facies ( $C L H$ from $31.1 \mathrm{~m}$ to $34.4 \mathrm{~m}$ ), are slightly outside of the calculated grain sizes, suggesting an external forcing (Fig. 18).

\subsection{Significance of the shape of the velocity/grain size vertical profile}

Our results show that the shape of the velocity/grain size vertical profile used is crucial to assess the impact of the channel levee height on the grain size of a levee deposits. The shape of the profile of Stacey and Bowen (1988b) is very similar to those described in most of models such as those of Felix (2002) or Kneller \& Buckee (2000). It corresponds to currents with continuous 
concentration, characteristic of the equilibrium of weakly depositional turbidity currents on low slopes, as presented in Peakall et al. (2000). Noteworthy is the similarity between the grain size profile from Migeon (2000) and the concentration profiles shown in Stacey and Bowen (1988b), Kneller \& Buckee (2000) and Felix (2002). It actually corresponds to the continuous concentration profile shown in Peakall et al. (2000). This shows that the velocity profile of a turbidity current does not describe the vertical grain size distribution. It demonstrates the close relationship between the concentration profile and the grain size profile, as mentioned by Peakall et al. (2000). This relationship involves grain-grain interactions that improve the ability of a turbidity current to carry coarse sediment at low velocity. This ability is an equilibrium between the vertical density profile of the current (i-e, its concentration) and its vertical velocity profile. As the profile of Migeon (2000) is a "sedimentological" profile, it obviously takes these interactions in account. It is, therefore, the most suitable profile for assessing the impact of the levee aggradation on the grain size of sediments deposited by overflow processes. The calculations based on the profile of Stacey and Bowen (1988b), should incorporate in equation (3) a variable fluid density, correlated to the concentration profile.

\subsection{Autocyclic versus allocyclic control on the vertical trend of the turbidite facies?}

We obviously have too many unknown parameters ( $C B G S$, the real behaviour of the $C L H$ through time, transport processes on the surface of the levee, and of course the real significance of the velocity/grain size profiles) to fully determine the impact of the levee aggradation on the turbidite facies. Nevertheless, with realistic parameters and the bathymeric constraints, we can affirm that, according to the vertical grain size profile of Migeon (2000), the vertical fining-up trend of the median grain size at the bottom of the turbidite beds, observed in core MD99-2344, 
can be fully explained by the progressive confinement of the turbidity currents, in relation to levee aggradation. However, the superimposed high amplitude variations are not described by our calculation and must be controlled by some external forcing. In other words, the progressive confinement of turbidity currents has impact only the trend (fining-up) of the grain size of spillover deposits but a enables recording the relative random variability (external forcing) of $T C T \mathrm{~s}$. In addition, from $5.81 \mathrm{~m}$ to $3.50 \mathrm{~m}$ the fining-up trend is slightly different and cannot be predicted by our calculations, so may also be related to external forcing, possibly the deglacial sea level rise, as suggested by the age of $18.6 \mathrm{ky} \mathrm{BP}$ (C-14 scale) postulated by Beaudouin et al. (2004) at the depth of $7.06 \mathrm{~m}$. During that period TCT s may not vary randomly and progressively decrease, for instance. This externally forced trend will overprint the upward fining trend driven by the levee aggradation and consequent progressive confinement of the turbidity currents.

The calculations based on the profile of Migeon (2000), have shown that for TCTs higher than the $C L H$, the grain size of leveed turbidite deposits decreases exponentially when the $C L H$ increases linearly, as shown by equation (10), and that when the $C L H$ reaches about half of the $T C T$, the decrease of the grain size of deposited sediments becomes very slow. At this point, the impact of the aggradation of a levee on the grain size of turbidite facies becomes almost undetectable (Fig. 19). This explains why leveed turbidite facies with very high CLH do not display any fining upward, as in proximal area of the Zaïre deep-sea fan (Gervais et al., 2001) and the Var sedimentary ridge (Migeon et al., 2000). This internal forcing must be recorded at the termination of turbidite channels where levees are poorly developed. In well-developed levees or fossil deep-sea fan it may be recorded at the base of the levees during the early stage of growth. 


\section{Conclusions}

Our study shows that, according to the grain-size vertical profile of Migeon (2000), the fining upward of the median can be solely explained by the aggradation of the turbidite levee of the Petit-Rhône neofan.

The record of this internal variability for the turbidite facies depends on the ratio of turbidity current thickness and the channel-levee height. This internal variability is visible on the turbidite facies (upward fining up of the bottom of the successive turbidite beds) on a few metres when the channel-levee height is less than half of the turbidity current thickness. Otherwise, the impact on the turbidite facies is almost insignificant. Therefore, for distal turbidite systems with low channel-levee heights, like the Petit-Rhône neofan, the aggradation of the turbidite levee has a preponderant control on the vertical (temporal) variability of the turbidite facies. It results in a low frequency variation of the grain size, corresponding to a fining upward.

Strictly speaking, the growth of the levee is externally forced by the sediment input from the source expressed as $T C T$ in our calculations. Nevertheless, the grain size in the turbidite facies shows two orders of variability: (1) a high frequency variability interpreted as allocyclic and forced by the source of the sediment, (2) a low frequency variability (trend) interpreted as autocyclic and forced by the growth of the levee and gradual confinement of the turbidity currents.

The choice of the vertical grain size/velocity profile for characterizing a turbidity current is crucial. It appears that vertical velocity profiles from models do not describe the true ability of turbidity currents to transport coarse sediments. The concentration of sediment is preponderant, as it controls the density of a turbidite current and, therefore, its ability to transport coarse 
sediment. This explains why the shape of vertical grain size distribution from Migeon (2000) is similar to the concentration profiles from other models.

The high frequency and high amplitude, variability of the grain size is controlled by external forcing (allocyclicity) probably related to continental climate change and/or changes in the position of the river delta. They may also be related to processes driven by the interaction between the spillover flow and the channel-levee morphologies such as meanders or bedforms.

This simple quantification of the impact of the levee aggradation on the turbidite facies allows to predict the grain size of such deposits when the channel levee height and the grain size in the turbidite channel are constrained. Thus, it allows a better quantification of the reservoir potential of the turbidite leveed facies identified on seismic data.

\section{Acknowledgements}

The authors would like to thank the captain, crew and shipboard party of R/V Marion Dufresne 2 cruise MD114, and particularly Yvon Balut from Institut Paul Emile Victor (IPEV, French polar institute) and the Malagasy crew. The core MD99-2344 was retrieved during the IMAGES V cruise of the international programme IMAGES. Nabil Sultan and Michel Voisset are thanked for giving shiptime during cruise GMO2-CARNAC on R/V Le Suroît and the acquisition of chirp profile from Figure 4. Captain and crew of R/V Le Suroît are thanked for the acquisition of acoustic and seismic data during the cruise MARION. This study was supported by the French national programme "GDR Marges", the "URM17" research group and the Framework Programme 5 European project "Eurostrataform" (contract \#EVK3-CT-2002-00079). Ronan Apprioual is thanked for his help in the acquisition of digital photographs and the preparation of slabs for X-ray photographs. Joël Saint-Paul and Olivier Weber (Université Bordeaux I) are 
thanked for their help in the acquisition of the X-ray photographs. Michaele Kashgarian (Lawrence Livermore National Laboratory, USA) is thanked for AMS radiocarbon datations. Sébastien Migeon provided fruitful comments in an early stage of the manuscript. Bruno Savoye is thanked for his help in improving the manuscript. The paper has been significantly improved by reviews from Thierry Mulder, Russel Wynn and Angelo Camerlenghi.

\section{Appendix: list of acronyms}

$C B G S=$ Channel Bottom Grain Size $(\mu \mathrm{m})$

$C B V=$ Channel Bottom Velocity $\left(\mathrm{m} \cdot \mathrm{s}^{-1}\right)$

$C L H=$ Channel-Levee Heigh $(\mathrm{m})$

$C L H 1=$ Channel-Levee Height at deposition of a given silt bed $(\mathrm{m})$

CLH2 $=$ Present Channel-Levee Height $=39 \mathrm{~m}$

$D C=$ Depth in the sediment core $(\mathrm{m})$

$G S=$ Sample Grain Size $(\mu \mathrm{m})$

$l=D C 2-D C 1=$ Levee aggradation at the location of core MD99-2344 (m)

$L=C L H 2-C L H 1=$ Levee aggradation at the crest of the levee $(\mathrm{m})$

$\frac{L}{l}=1.34$

lh = Levee height at the location of core MD99-2344 (m)

$T C T=$ Turbidite Current Thickness $(\mathrm{m})$

$V=$ Sample Velocity $\left(\mathrm{m} \cdot \mathrm{s}^{-1}\right)$

$W D=$ Water depth $(\mathrm{m})$

\section{References}


Beaudouin, C., Dennielou, B., Melki, T., Guichard, F., Kallel, N., Berne, S. and Huchon, A., 2004. The Late-Quaternary climatic signal recorded in a deep-sea turbiditic levee (Rhône Neofan, Gulf of Lions, NW Mediterranean): palynological constraints. Sedimentary Geology, 172, 85-97.

Beaudouin, C., Suc, J.-P., Cambon, G., Touzani, A., Giresse, P., Pont, D., Aloïsi, J.-C., Marsset, T., Cochonat, P., Duzer, D. and Ferrier, J., 2005. Present-day rhythmic deposition in the Grand Rhône prodelta (NW Mediterrenean) according to high-resolution pollen analyses. Journal of Coastal Reasearch, 21, 292-306.

Berné, S., Carré, D., Loubrieu, B., Mazé, J.-P. and Normand, A., 2001. Carte morphobathymétrique du Golfe du Lion. Ifremer-Région Languedoc-Roussillon, Brest.

Bonnel, C., Dennielou, B., Berné, S., Mulder, T. and Droz, L., 2005. Architecture and depositional pattern of the Rhône Neofan and recent gravity activity in the Gulf of Lions (Western Mediterranean). Marine and Petroleum Geology, 22, 827-843.

Bouma, A.H., 1962. Sedimentology of some flysh deposits: a graphic approach to facies interpretation. Elsevier, Amsterdam, 168 pp.

Bouma, A.H., 2004. Key controls on characteristics of turbidite systems, in: S.A. Lomas and P. Joseph (Eds.), Confined Turbidite Systems. Geological Society of London, Special Publications, 222, pp. 9-22.

Bowen, A.J., Normark, W.R. and Piper, D.J.W., 1984. Modelling of turbidity currents on Navy submarine Fan, California continental borderland, Sedimentology, pp. 161-185.

Cambon, G., Suc, J.-P., Aloïsi, J.-C., Giresse, P., Monaco, A., Touzani, A., Duzer, D. and Ferrier, J., 1997. Modern pollen deposition in the Rhône delta area (lagoonal and marine sediments), France. Grana, 36, 105-113. 
Carter, L., Carter, R.M., Nelson, C.S., Fulthorpe, C.S. and Neil, H.L., 1990. Evolution of Pliocene to Recent abyssal sediment waves on Bounty Channel levees, New Zealand. Marine Geology, 95, 97-109.

Cour, P., 1974. Nouvelles techniques de détection des flux et des retombées polliniques: étude de la sédimentation des pollens et des spores à la surface du sol. Pollen et Spores, 16, 103141.

Coutellier, V., 1985. Mise en évidence et rôle des mouvements gravitaires dans l'évolution de la marge continentale : exemple des marges du Golfe du Lion et de la Provence Occidentale. PhD Thesis, Université Pierre et Marie Curie (Paris VI), 197 pp.

Dennielou, B., Bonnel, C., Sultan, N., Voisset, M., Berné, S. and Droz, L., 2003. Sand transfer into the deep basin of the Gulf of Lions: even during the sea level high stand...! In: J. Mienert, S. Guidard and K.R. Mortensen (Editors), Ocean Margin Research Conference, Paris, pp. 129.

Droz, L., 1983. L'éventail sous-marin profond du Rhône (Golfe du lion) : grands traits morphologiques et structure semi-profonde. PhD Thesis, Université Paris VI, Paris, 195 pp.

Droz, L. and Bellaiche, G., 1985. Rhône Deep-Sea Fan: morphostructure and growth pattern. American Association of Petroleum Geologists Bulletin, 69, 460-479.

Droz, L., Canals, M., Dennielou, B., Ivanov, M.K., Amblas, D., Lastras, G., Akhmetzhanov, A. and Parties, P.a.T.L.S.S., Submitted. New insights into the initiation of turbidite channel formation, Petit-Rhône neofan, Gulf of Lions, Western Mediterranean. Geology.

Droz, L., Kergoat, R., Cochonat, P. and Berné, S., 2001. Recent sedimentary events in the western Gulf of Lions (Western Mediterranean). Marine Geology, 176, 23-37. 
Felix, M., 2002. Flow structure of turbidity currents. Sedimentology, 49, 397-419.

Flood, R.C., Manley, P.L., Kowsmann, K.O., Appi, C.J. and Pirmez, C., 1991. Seismic facies and late Quaternary growth of Amazon submarine fan, in: P. Weimer and M.H. Link (Eds.), Seismic Facies and Sedimentary Processes of Submarine Fans and Turbidite Systems. Springer-Verlag, NewYork, pp. 415-434.

Flood, R.D., Piper, D.J.W., Klaus, A. and al., e., 1995. Proc. ODP, Init. Repts., 155. Ocean Drilling Program, College Station, TX.

Gaudin, M., Berné, S., Jouanneau, J.-M., Palanques, A., Cirac, P., Mulder, T. and Rabineau, M., this issue. Massive sand beds deposited by dense water cascading in the Bourcart canyon head, Gulf of Lions (northwestern Mediterranean Sea). Marine Geology.

Gaullier, V., Antonini, E., Benkhelil, J. and Got, H., 1998. Recent gravity-driven sedimentary bodies in the North-Balearic Basin: geometry and quantification. Comptes Rendus de l'Academie des Sciences - Series IIA - Earth and Planetary Science, 327, 677-684.

Gervais, A., Mulder, T., Savoye, B., Migeon, S. and Cremer, M., 2001. Recent processes of levee formation on the Zaire deep-sea fan. Comptes Rendus de l'Academie des Sciences - Series IIA - Earth and Planetary Science, 332, 371-378.

Hiscott, R.N., Hall, F.R. and Pirmez, C., 1995. Turbidity-current overspill from the Amazon channel: Texture of the silt/sand load, paleoflow from anisotropy of magnetic susceptibility and implication for flow processes, in: R.D. Flood, D.J.W. Piper, A. Klaus and L.C. Peterson (Eds.), Proceedings of the Ocean Drilling Program, Initial Reports. Ocean Drilling Program, College Station, TX, 155, pp. 53-78.

Hiscott, R.N., Pirmez, C. and Flood, R.D., 1997. Amazon Submarine Fan Drilling: A Big Step Forward For Deep-sea Fan Models. Geoscience Canada, 24, 13-24. 
Holdich, R., 2002. Fundamentals of Particle Technology. Midland Information Technology \& Publishing.

Kenyon, N.H., Millington, J., Droz, L. and Ivanov, M.K., 1995. Scour holes in a channel-lobe transition zone on the Rhône cone, in: K.T. Pickering, R.N. Hiscott, N.H. Kenyon, F.R. Lucchi and R.D.A. Smith (Eds.), Atlas of Deep-water Environments: Architectural Styles in Turbidite Systems. Chapman and Hall, London, pp. 212-215.

Klaucke, I., Hesse, R. and Ryan, W.B.F., 1997. Flow parameters of turbidity currents in a lowsinuosity giant deep-sea channel. Sedimentology, 44, 1093-1102.

Kneller, B. and Buckee, C., 2000. The structure and fluid mechanics of turbidity currents: a review of some recent studies and their geological implications. Sedimentology, 47, 6294.

Lambeck, K., Yokoyama, Y. and Purcell, T., 2002. Into and out of the Last Glacial Maximum: sea-level change during Oxygen Isotope Stages 3 and 2. Quaternary Science Reviews, 21, 343-360.

Lofi, J. and Weber, O., 2001. SCOPIX - digital processing of X-ray images for the enhancement of sedimentary structures in undisturbed core slabs. Geo-Marine Letters, 20, 182-186.

Lopez, M., 2001. Architecture and depositional pattern of the Quaternary deep-sea fan of the Amazon. Marine and Petroleum Geology, 18, 479-486.

Manley, L.P., Pirmez, C., Busch, W. and Cramp, A., 1997. Grain-size characterization of Amazon fan deposits and comparison to seismic facies units. Proceedings of the Ocean Drilling Program, Scientific Results, 155. Ocean Drilling Program, College Station, TX, $35-52 \mathrm{pp}$. 
Méar, Y., 1984. Séquences et unités sédimentaires du glacis rhôdanien (Méditerranée occidentale). PhD Thesis, Perpignan.

Méar, Y. and Gensous, B., 1993. Processus d'édification d'une unite interlobe; application au deep-sea fan du Petit-Rhône. Comptes Rendus de l'Académie des Sciences, Serie II, Mécanique, Physique, Chimie, Sciences de l'Univers, Sciences de la Terre, 317, 16331640.

Migeon, S., 2000. Dunes géantes et levées sédimentaires en domaine marin profond : approche morphologique, sismique et sédimentologique. PhD Thesis, Université Bordeaux 1, Talence, France, 288 pp.

Migeon, S., Savoye, B., Babonneau, N. and Spy-Anderson, F.-L., 2004. Processes of sedimentwaves construction along the present Zaire Deep-sea meandering channel: role of meanders and flow stripping. Journal of Sedimentary Research, 74, 580-598.

Migeon, S., Savoye, B. and Faugeres, J.-C., 2000. Quaternary development of migrating sediment waves in the Var deep-sea fan: distribution, growth pattern, and implication for levee evolution. Sedimentary Geology, 133, 265-293.

Migeon, S., Savoye, B., Zanella, E., Mulder, T., Faugères, J.-C. and Weber, O., 2001. Detailed seismic-reflection and sedimentary study of turbidite sediment waves on the Var Sedimentary Ridge (SE France): significance for sediment transport and deposition and for the mechanisms of sediment-wave construction. Marine and Petroleum Geology, 18, 179-208.

Migeon, S., Weber, O., Faugères, J.-C. and Saint-Paul, J., 1999. SCOPIX: A new X-ray imaging system for core analysis. Geo-Marine Letters, 18, 251-255. 
Mulder, Migeon, Savoye and Faugères, 2002. Reply to discussion by Shanmugam on Mulder et al. (2001, Geo-Marine Letters 21: 86-93) Inversely graded turbidite sequences in the deep Mediterranean. A record of deposits from flood-generated turbidity currents? Geo-Marine Letters, 22, 112-120.

Mulder, T., Migeon, S., Savoye, B. and Faugères, J.-C., 2001. Inversely graded turbidite sequences in the deep Mediterranean: a record of deposits from flood-generated turbidity currents? Geo-marine letters, 21, 86-93.

Mulder, T., Savoye, B. and Syvitski, J.P.M., 1997. Numerical modelling of a mid-sized gravity flow : the 1979 Nice turbidity current (dynamics, processes, sediment budget and seafloor impact). Sedimentology, 44, 305-326.

Nakagima, T. and Satoh, M., 2001. The formation of large mudwaves by turbidity currents on the levees of the Toyama deep-sea channel, Japan Sea. Sedimentology, 48, 435-463.

Normark, W.R., Piper, D.J.W., Posamentier, H., Pirmez, C. and Migeon, S., 2002. Variability in form and growth of sediment waves on turbidite channel levees. Marine Geology, 192, 23-58.

Peakall, J., McCaffrey, B. and Kneller, B., 2000. A process model for the evolution, morphology, and architecture of sinuous submarine channels. Journal of Sedimentary Research, 70, 434-448.

Piper, D.J.W. and Deptuck, M., 1995. Fine-Grained Turbidites of the Amazon Fan: Facies Characterization and Interpretation, in: R.D. Flood, D.J.W. Piper, A. Klaus and L.C. Peterson (Eds.), Proceedings of the Ocean Drilling Program, Initial Reports. Ocean Drilling Program, College Station, TX, 155, pp. 77-108. 
Piper, D.J.W. and Stow, D.A.V., 1991. Fine-grained turbidites, in: Einsele (Ed.), Cycles and Events in Stratigraphy. Springer-Verlag, Berlin Heidelberg, pp. 360-376.

Pirmez, C. and Imran, J., 2003. Reconstruction of turbidity currents in Amazon Channel. Marine and Petroleum Geology, 20, 823-849.

Salaheldin, T.M., Imran, J., Chaudhry, M.H. and Reed, C., 2000. Role of fine-grained sediment in turbidity current flow dynamics and resulting deposits. Marine Geology, 171, 21-38.

Savoye, B., Cochonat, P., Apprioual, R., Bain, O., Baltzer, A., Bellec, V., Beuzart, P., Bourillet, J.-F., Cagna, R. and Cremer, M., 2000. Structure et evolution recente de l'eventail turbiditique du Zaire : premiers resultats scientifiques des missions d'exploration Zaiango1 \& 2 (marge Congo-Angola): Structure and recent evolution of the Zaire deepsea fan: preliminary results of the ZaiAngo $1 \& 2$ cruises (Angola-Congo margin). Comptes Rendus de l'Académie des Sciences - Series IIA - Earth and Planetary Science, 331, 211-220.

Savoye, B., Piper, D.J.W. and Droz, L., 1993. Plio-Pleistocene evolution of the Var deep-sea fan off the French Riviera. Marine and Petroleum Geology, 10, 550-571.

Showers, J.W., Scheinder, R., Mikkelsen, N. and Maslin, M., 1997. Isotopic stratigraphy of Amazon fan sediments, in: R.D. Flood, D.J.W. Piper, A. Klaus and L.C. Peterson (Eds.), Proceedings of the Ocean Drilling Program, Scientific Results. Ocean Drilling Program, College Station, TX, 155, pp. 281-303.

Stacey, M. and Bowen, A.J., 1988a. The vertical structure of density and turbidity currents: theory and observations, Journal of Geophysical Research, pp. 3528-3542.

Stacey, M. and Bowen, A.J., 1988b. The vertical structure of turbidity currents and a necessary condition for self-maintenance, Journal of Geophysical Research, pp. 3543-3553. 
Stow, D.A.V. and Bowen, A.J., 1980. A physical model for the transport and sorting of finegrained sediment by turbidity currents, Sedimentology, pp. 31-46.

Stow, D.A.V. and Piper, D.J.W., 1984. Deep-water fine-grained sediments: facies models, in: D.A.V. Stow and D.J. Piper (Eds.), Fine-Grained sediments: Deep-Water processes and Facies. Blackwell Scientific Publications, Geological Society Special Publication, pp. 612-646.

Stuiver, M., Reimer, P.J., Bard, E., Beck, J.W., Burr, G.S., Hughen, K.A., Kromer, B., McCormac, G., van der Plicht, J. and Spurk, M., 1998. INTCAL98 Radiocarbon Age Calibration, 24000-0 cal BP. Radiocarbon, 40, 1041-1083.

Torres, J., Droz, L., Savoye, B., Terentieva, E., Cochonat, P., Kenyon, N.H. and Canals, M., 1997. Deep-sea avulsion and morphosedimentary evolution of the Rhône Fan Valley and Neofan during the Late Quaternary (north-western Mediterranean Sea). Sedimentology, 44, 457-477.

Wynn, R.B. and Stow, D.A.V., 2002. Recognition and interpretation of deep-water sediment waves: implications for palaeoceanography, hydrocarbon exploration and flow process interpretation. Marine Geology, 192, 1-3. 


\section{Tables and figures legends}

Table 1: AMS radiocarbon ages in core MD99-2344 measured on Globigerina bulloides.. Calibrated ages are calculated with Calib 4.3 (Stuiver et al., 1998).

Table 2: Coefficients of equations (7) and (8) from the vertical velocity profile of Stacey and Bowen (1988b) for channel bottom grain sizes ranging from 70-400 $\mu \mathrm{m}$.

Table 3: Coefficients of equations (9) and (10) from the vertical velocity profile of Migeon (2000) for channel bottom grain sizes ranging from 70-400 $\mu \mathrm{m}$.

Figure 1: Location map of the study area in the Gulf of Lions. The box indicates the location of Figure 2.

Figure 2: Illuminated bathymetry map of the Petit-Rhône Neofan. Location of the sediment core MD99-2344. AB represents the cross sections presented in Figure 3 and Figure 4. The dashed line represents the Petit-Rhône Paleochannel. The continuous line represents the Petit-Rhône Neochannel. PLR = Pyreneo-Languedocian Ridge.

Figure 3: Schematic cross section on the Petit-Rhône Neofan (see Figure 2 for location), created from the swath bathymetry map and from the isopach maps of Bonnel et al. (2005). See location of the neochannel and of sediment core MD99-2344 on the right levee. NTU = Neofan Transparent Unit; NCU = Neofan Chaotic Unit; WDF = Western Debris Flow; 
RDSF $=$ petit-Rhône Deep-Sea Fan. Depths were calculated with a reference sound velocity of $1.5 \mathrm{~km} \cdot \mathrm{s}^{-1}$.

Figure 4: Chirp cross section on the Petit-Rhône Neofan (see Fig. 2 for location). See location of the neochannel and of sediment core MD99-2344 on the right levee. The dashed line shows the base of the Neofan Transparent Unit (NTU) and the top of the Neofan Chaotic Unit (NCU).

Figure 5: Sedimentary log of core MD99-2344. See the number of graded beds interpreted as fine-grained turbidites, and the corresponding fining upward of the base of the coarse beds. a) median $(\mu \mathrm{m})$ for all sedimentary facies; see the remarkable normal grading and alternating coarse/mud beds, b) median at the base of the silty beds; see the clear fining upward trend and the high amplitude and high frequency variability, c) along core carbonate content, d) relative pollen and dinocyst content, interpreted as relative continental and fluvial input.

Figure 6: Turbidite facies 1. a) X-ray image; b - processed X-ray image; c) photograph; d) median $(\mu \mathrm{m})$ of the sediment. Open circles indicate the position of the grain size samples. Squares indicate the zooms shown in Figure 10. Note that coarse silt beds are thicker than the clay beds, and the silt laminae in the clay beds (up to 4 per $\mathrm{cm}$ ).

Figure 7: Turbidite facies 2. a) X-ray image; b) processed X-ray image; c - photograph; d) median $(\mu \mathrm{m})$ of the sediment. Open circles indicate the position of the grain size samples. 
Squares indicate the zooms shown in Figure 10. Note the equivalent thickness of the coarse silt beds and clay bed, and the laminae

Figure 8: Turbidite facies 3. a) X-ray image; b) processed X-ray image; c) photograph; d) median $(\mu \mathrm{m})$ of the sediment. Open circles indicate the position of the grain size samples. Squares indicate the zooms shown in Figure 10. Note the amount of silt laminae (about 16 per ten $\mathrm{cm})$ whose thicknesses range from few millimetres to infra-millimetric. The upward convex bending is a coring artefact.

Figure 9: Turbidite facies 4. a) X-ray image; b) processed X-ray image; c) photograph; d median $(\mu \mathrm{m})$ of the sediment. Open circles indicate the position of the grain size samples. Squares indicate the zooms shown in Figure 10. See the millimetric and infra-millimetric silt laminae. The upward convex bending is a coring artefact.

Figure 10: Close-up views on Turbidite facies 1, 2, 3 and 4 - Left, processed X-ray image, right, image. Note the scale on the upper right corner of the photos.

Figure 11: Schematic drawing showing the relation between the several discussed parameters and the channel-levee geometry of the Petit-Rhône neofan. Note the position of core MD992344 in the system. TCT = Turbidity Current Thickness; $C L H=$ Channel-Levee Height; $C B G S=$ Channel Bottom Grain Size; $D C=$ Depth in the sediment core $W D=$ Water Depth; $l h=$ Levee height at the location of the core; $L=$ levee aggradation; $l=$ levee aggradation a the core location. 
Figure 12: Vertical velocity profile from Stacey and Bowen (1988b) (a) and the corresponding vertical grain size profile (b) according to equations (1), (2), (3) and (7. See the example for the graphical method used to calculate the $T C T$, according to the $C L H$ and the $C B G S$ or the $C B V$. The black curve represents the fitted curve, in order to enable the calculations via a spreadsheet and equations (7) and (8). CBV $=$ Channel Bottom Velocity, for other acronyms see Fig. 11.

Figure 13: Vertical grain size profile from Migeon (2000) (b) and the corresponding vertical velocity profile (a) according to equations (1), (2), (3) and (7). See the example for the graphical method used to calculate the $T C T$, according to the $C L H$ and the $C B G S$ or the $C B V$. The black curve represents the fitted curve, in order to enable the calculations via a spreadsheet and equations (9) and (10). For acronyms, see Figs. 11 and 12.

Figure 14: Calculated thickness of the turbidity currents corresponding to the turbidite beds described on core MD99-2344. The calculation is made using the velocity profile of Stacey and Bowen (1988b).a) TCT s calculated for $C B G S$ values ranging from $150 \mu \mathrm{m}$ to $300 \mu \mathrm{m}$. b) $T C T$ s calculated for $C B G S$ values ranging from $70 \mu \mathrm{m}$ to $120 \mu \mathrm{m}$. For acronyms, see Figs. 11 and 12.

Figure 15: Calculated thickness of the turbidite currents corresponding to the turbidite beds described on core MD99-2344. The calculation is made using to the grain size profile of 
Migeon (2000). , a) $T C T$ s calculated for $C B G S$ values ranging from $150 \mu \mathrm{m}$ to $400 \mu \mathrm{m}$.

b) $T C T \mathrm{~s}$ calculated for $C B G S$ values ranging from $70 \mu \mathrm{m}$ to $120 \mu \mathrm{m}$. For acronyms, see Figs. 11 and 12.

Figure 16: Variation of the $T C T$ as a function of the $C B G S$, calculated using the vertical profiles from Stacey and Bowen (1988b) (solid line) and Migeon (2000) (dash line). Note that the currents are thicker for the profile of Migeon (2000). For both profiles the thickness decreases with increasing $C B G S$. For acronyms, see Figs. 11 and 12.

Figure 17: Calculated GS of levee turbidite deposits according to the vertical profile from Stacey and Bowen (1988b) for several $C B G S \mathrm{~s}$ and several $T C T$

. a) $G S$ calculated for a TCT of $30 \mathrm{~m}$ and $C B G S$ ranging from70 $\mu \mathrm{m}$ to $300 \mu \mathrm{m}$, b) $G S$ calculated for a TCT of $35 \mathrm{~m}$ and $C B G S$ ranging from70 $\mu \mathrm{m}$ to $300 \mu \mathrm{m}$, c) $G S$ calculated for a TCT of $40 \mathrm{~m}$ and $C B G S$ ranging from70 $\mu \mathrm{m}$ to $300 \mu \mathrm{m}$, d) $G S$ calculated for a TCT of $150 \mathrm{~m}$ and $C B G S$ ranging from70 $\mu \mathrm{m}$ to $300 \mu \mathrm{m}$. Note that the best fit with the grain size from core MD99-2344 is obtained for a $T C T$ of 35 metres and a $C B G S$ between 70 and $90 \mu \mathrm{m}$, and for a $T C T$ of 40 metres and a $C B G S$ of $70 \mu \mathrm{m}$. For acronyms, see Figs. 11 and 12.

Figure 18: Calculated GS of levee turbidite deposits according to the vertical profile from Migeon (2000) for several $C B G S$ and for several $T C T$ s. a) $G S$ calculated for a TCT of $38 \mathrm{~m}$ and $C B G S$ ranging from70 $\mu \mathrm{m}$ to $400 \mu \mathrm{m}, \mathrm{b}) G S$ calculated for a TCT of $58 \mathrm{~m}$ and $C B G S$ ranging from70 $\mu \mathrm{m}$ to $400 \mu \mathrm{m}$, c) $G S$ calculated for a TCT of $115 \mathrm{~m}$ and $C B G S$ ranging 
from70 $\mu \mathrm{m}$ to $400 \mu \mathrm{m}, \mathrm{d}) G S$ calculated for a TCT of $500 \mathrm{~m}$ and $C B G S$ ranging from70 $\mu \mathrm{m}$ to $400 \mu \mathrm{m}$. Note that the best fit with the grain size from core MD99-2344 is obtained for a $T C T$ of 38 metres and a $C B G S$ of $400 \mu \mathrm{m}$, and for a $T C T$ of 58 metres and a $C B G S$ of $200 \mu \mathrm{m}$. For acronyms, see Figs. 11 and 12.

Figure 19: Schematic cross section of a turbidity current and spillover processes. Relationship between the Channel-Levee Height ( $C L H)$, the Turbidity Current Thickness $(T C T)$ and the Grain Size $(G S)$ of leveed deposits. The thick line shows relative expected fining upward on the upper part of the levee. Marked fining up trend in turbidite facies is obtained for $T C T$ much higher than the $C L H$. Low $T C T$ do not imprint a marked trend in the grain size because they deposit particles from the upper part (low gradient) of the turbidity current. 


\begin{tabular}{llllll}
\hline Depth in core $(\mathrm{cm})$ & $\begin{array}{l}{ }^{14} \mathrm{C} \text { years BP } \\
(-400 \text { years })\end{array}$ & $\begin{array}{l}\text { Calibrated } \\
\text { years BP }\end{array}$ & $\begin{array}{l}\text { Accumulation } \\
\text { rates }\left(\mathrm{cm}^{-k a}{ }^{-1}\right)\end{array}$ & Method & Analysis \# \\
\hline $9-10$ & $2,280 \pm 40$ & 2,341 & 4.3 & AMS $^{14} \mathrm{C}$ & LLNL-73268 \\
$144-145$ & $13,195 \pm 35$ & 15,743 & 10.1 & AMS $^{14} \mathrm{C}$ & LLNL-87504 \\
$195-196$ & $14,400 \pm 35$ & 17,135 & 36.6 & AMS $^{14} \mathrm{C}$ & LLNL-87505 \\
$215-216$ & $14,610 \pm 40$ & 17,376 & 83.0 & AMS $^{14} \mathrm{C}$ & LLNL-87506 \\
$230-232$ & $15,110 \pm 40$ & 17,952 & 27.8 & AMS $^{14} \mathrm{C}$ & LLNL-73269 \\
\hline
\end{tabular}

Table 1 


\begin{tabular}{|c|c|c|c|c|c|c|}
\hline \multirow[b]{2}{*}{ Bottom grain size } & \multicolumn{3}{|c|}{ Equation (7) } & \multicolumn{3}{|l|}{ Equation (8) } \\
\hline & $\mathrm{a}$ & $\mathrm{b}$ & $\mathrm{c}$ & $\mathrm{a}$ & $\mathrm{b}$ & $\mathrm{c}$ \\
\hline $70 \mu \mathrm{m}$ & 4756.4 & -2720.6 & \multirow{6}{*}{338.05} & $4.5352010^{-7}$ & -0.00065 & 0.16775 \\
\hline $90 \mu \mathrm{m}$ & 1862.4 & -1702.4 & & $7.2476010^{-7}$ & -0.00104 & 0.26808 \\
\hline $120 \mu \mathrm{m}$ & 667.54 & -1019.2 & & $1.2106010^{-6}$ & -0.00173 & 0.44777 \\
\hline $150 \mu \mathrm{m}$ & 315.12 & -700.27 & & $1.7620010^{-6}$ & -0.00252 & 0.65172 \\
\hline $200 \mu \mathrm{m}$ & 126.85 & -444.29 & & $2.771010^{-6}$ & -0.00397 & 1.02720 \\
\hline $300 \mu \mathrm{m}$ & 42.391 & -256.84 & & $4.8039010^{-6}$ & -0.00686 & 1,77690 \\
\hline
\end{tabular}

Table 2 


\begin{tabular}{|c|c|c|c|c|}
\hline \multirow[b]{2}{*}{ Bottom grain size } & \multicolumn{2}{|c|}{ Equation (9) } & \multicolumn{2}{|c|}{ Equation (10) } \\
\hline & $\mathrm{a}$ & $\mathrm{b}$ & $\mathrm{a}$ & $\mathrm{b}$ \\
\hline $70 \mu \mathrm{m}$ & & 652.95 & 73.741 & \\
\hline $90 \mu \mathrm{m}$ & & 690.78 & 94.463 & \\
\hline $120 \mu \mathrm{m}$ & & 734.08 & 125.95 & \\
\hline $150 \mu \mathrm{m}$ & -150.52 & 767.67 & 157.44 & -0.0064 \\
\hline $200 \mu \mathrm{m}$ & & 810.97 & 209.92 & \\
\hline $300 \mu \mathrm{m}$ & & 872.00 & 314.88 & \\
\hline $400 \mu \mathrm{m}$ & & 915.30 & 419.83 & \\
\hline
\end{tabular}

Table 3 


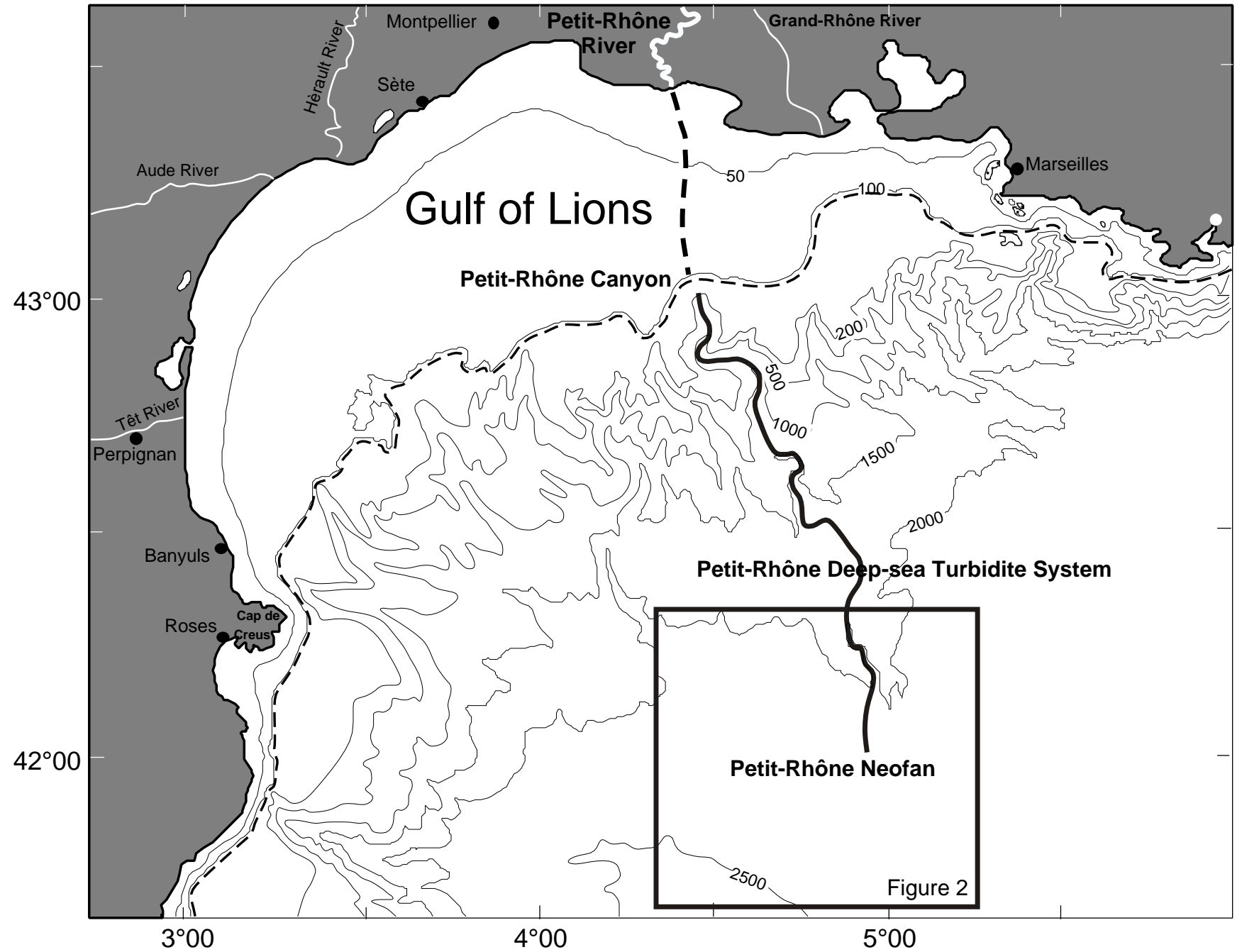

Dennielou et al., Figure 1 


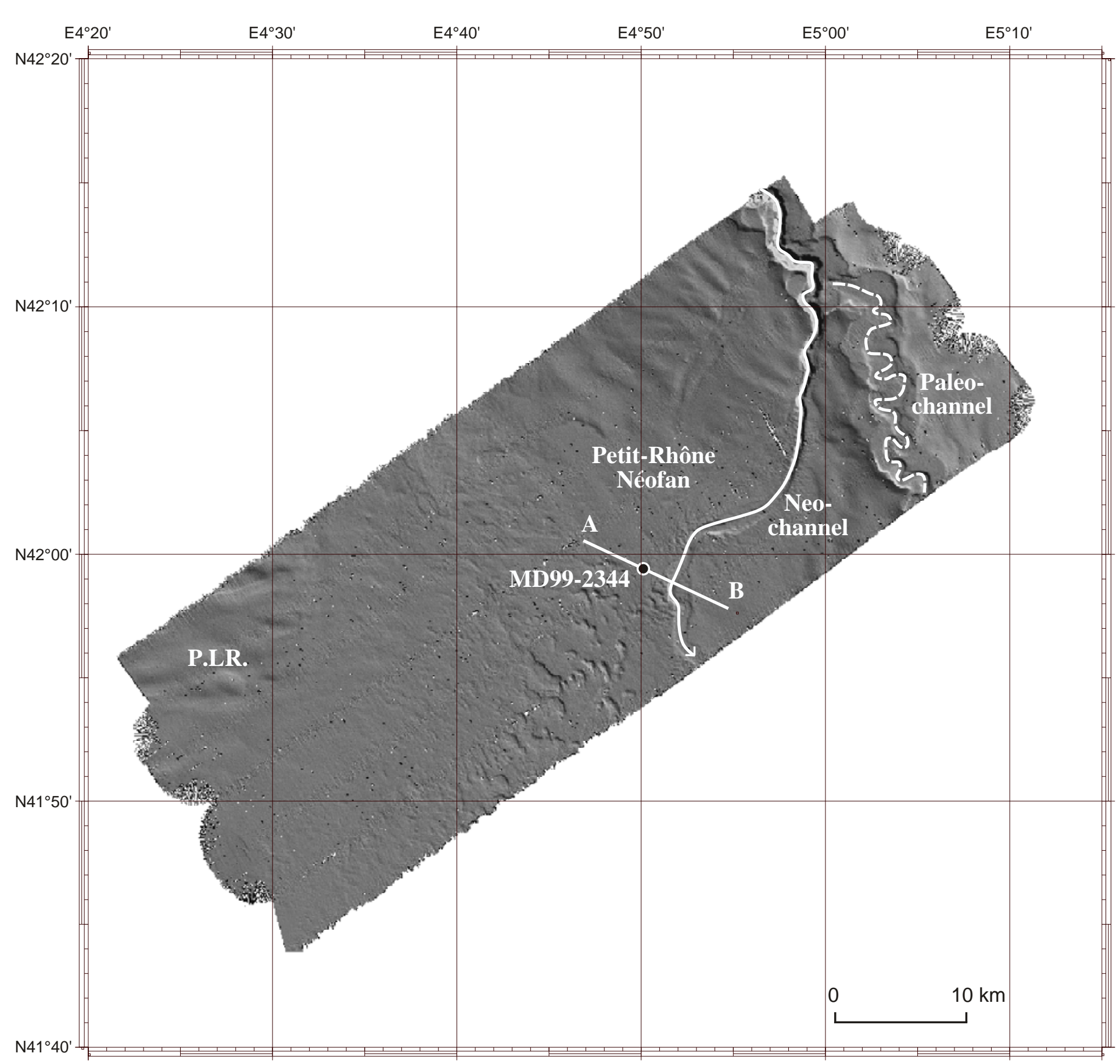

Dennielou et al., Figure 2 


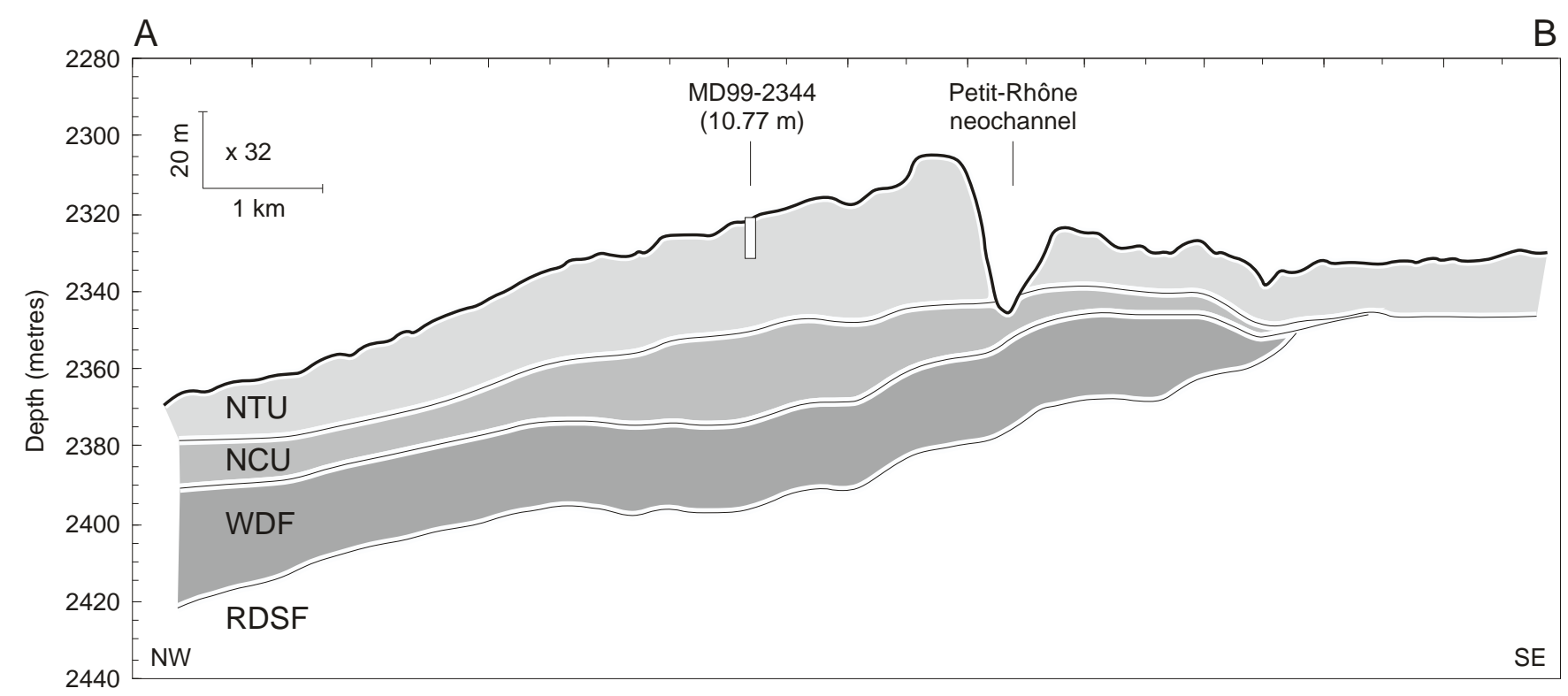

Dennielou et al., Figure 3 


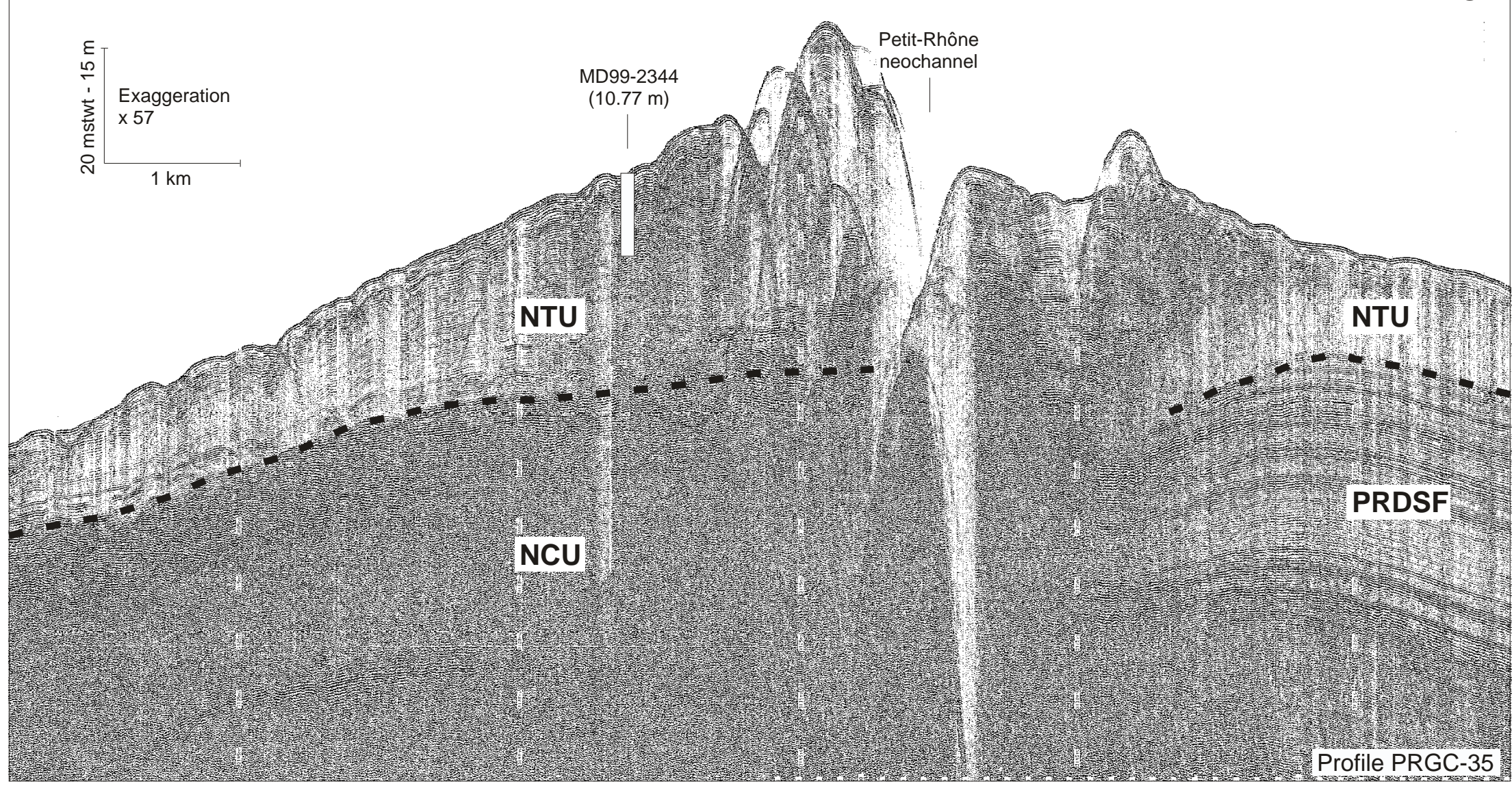

Dennielou et al., Figure 4 


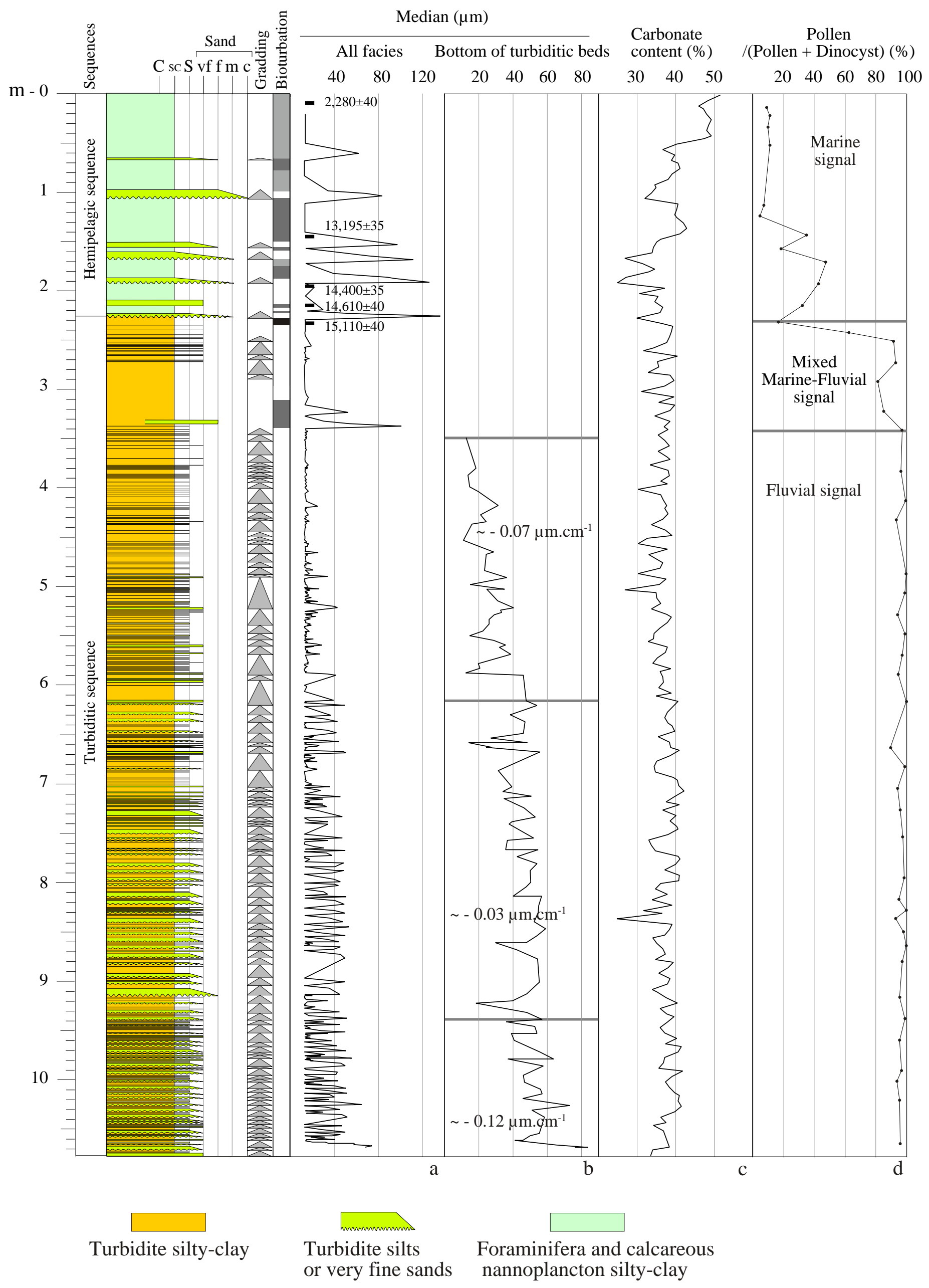

Dennielou et al., Figure 5 


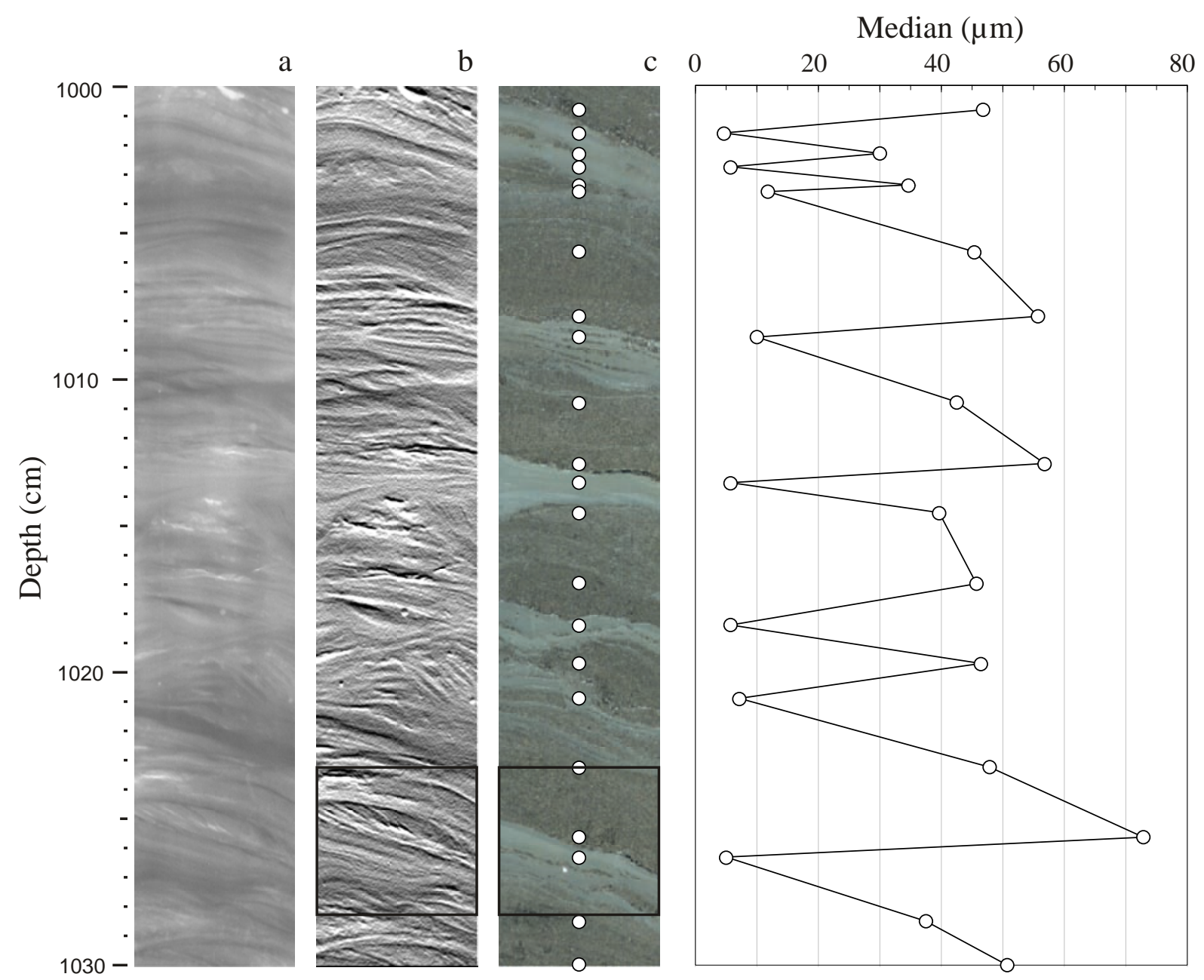

Turbidite facies 1 


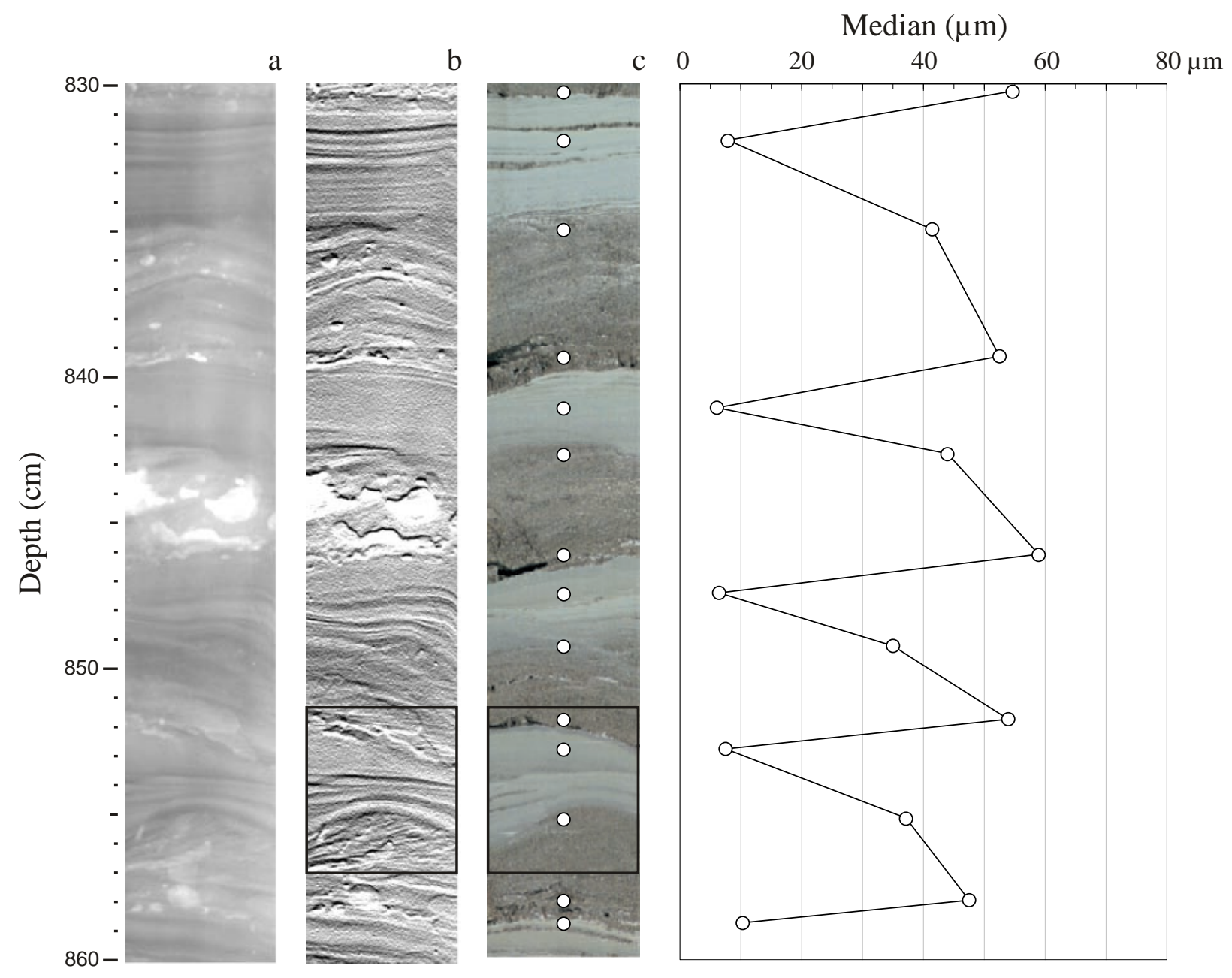

Turbiditic facies 2 


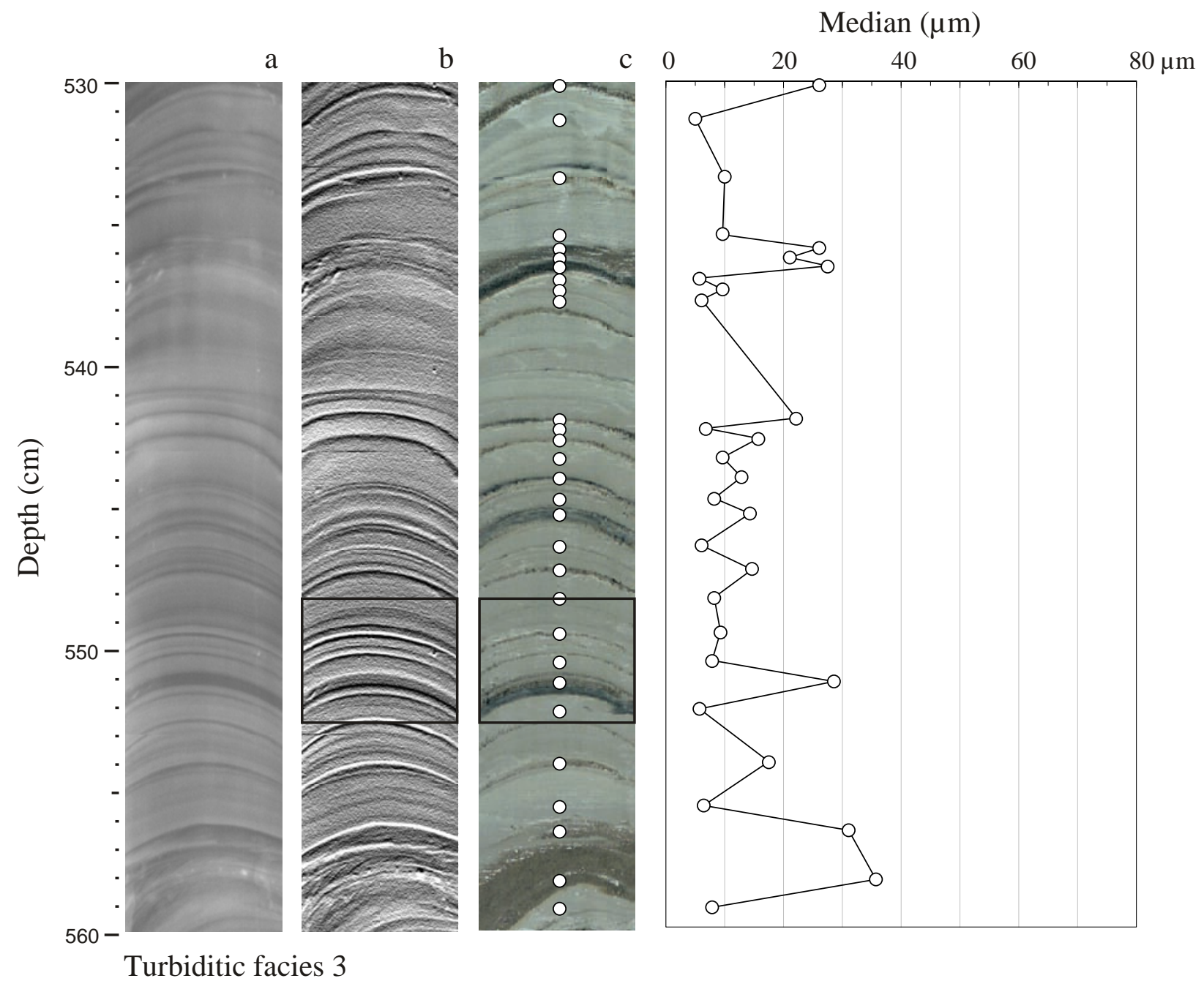

Dennielou et al., Figure 8 


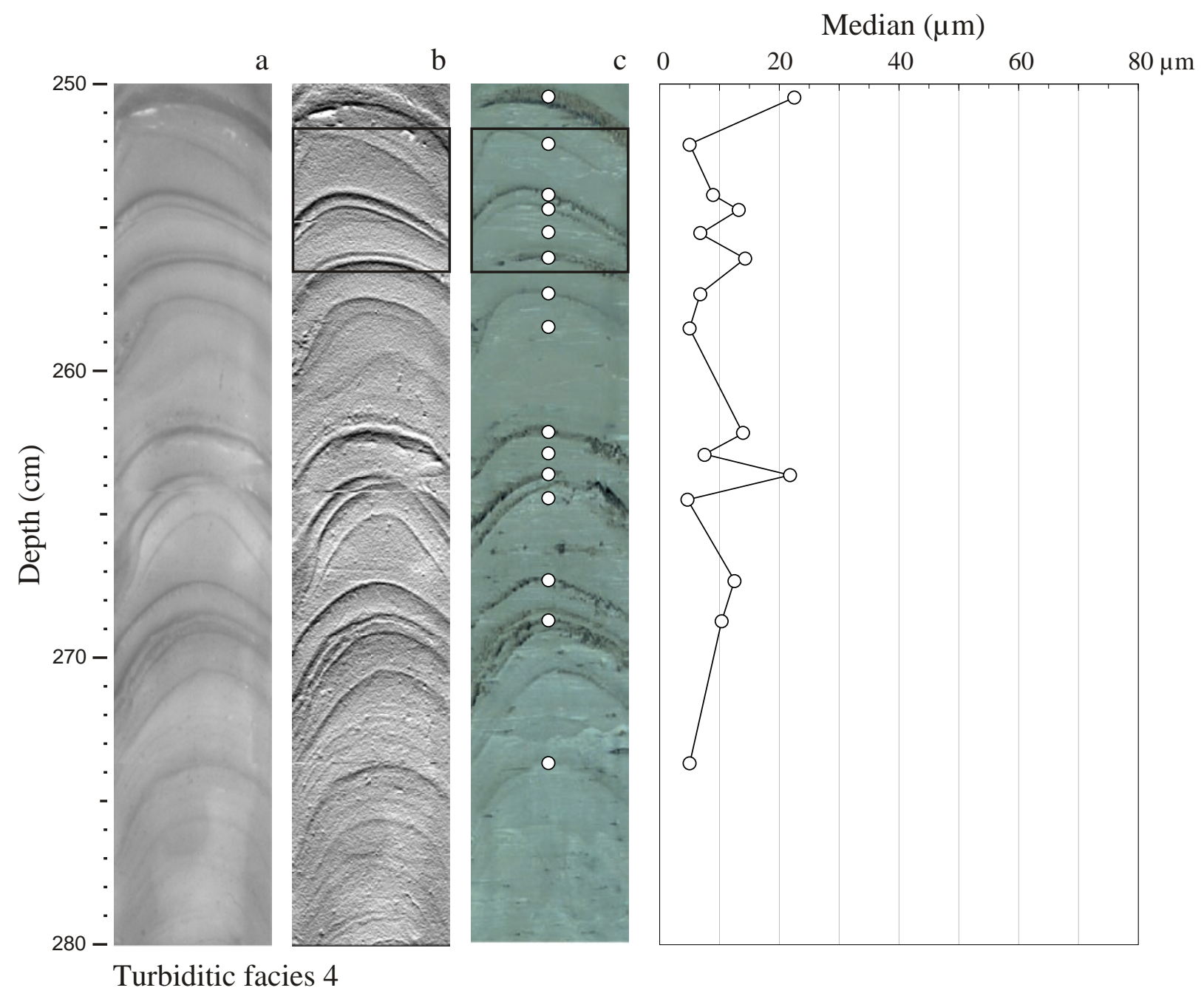

Dennielou et al., Figure 9 

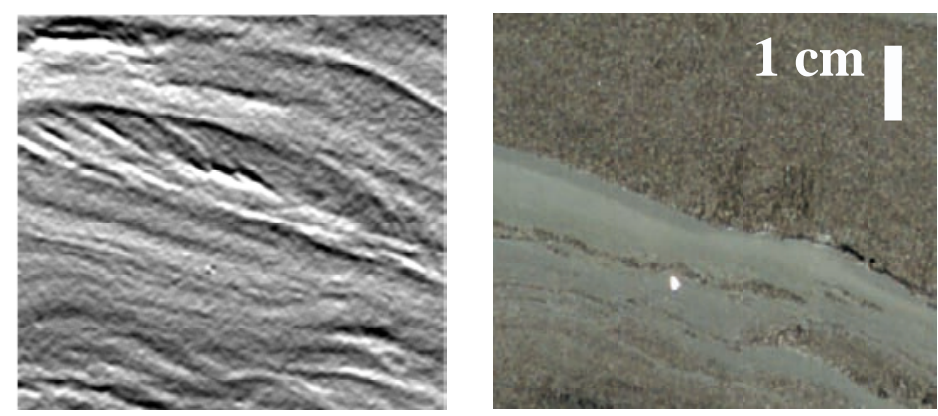

Turbidite facies 1
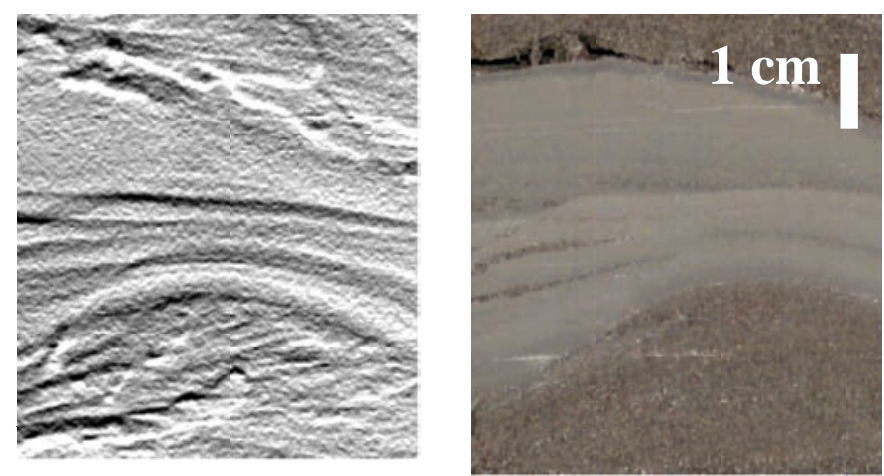

Turbidite facies 2
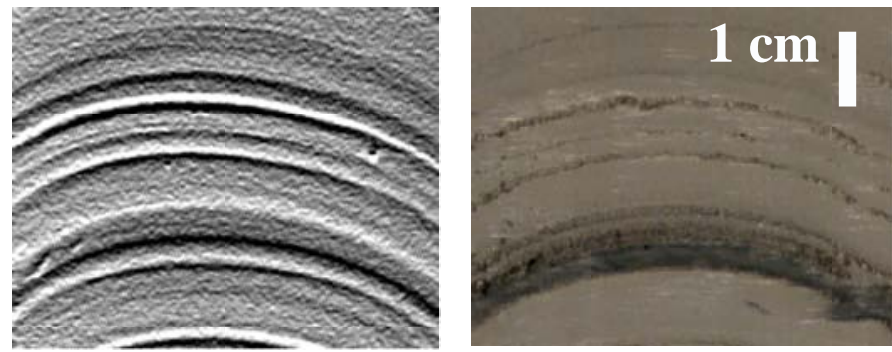

Turbidite facies 3
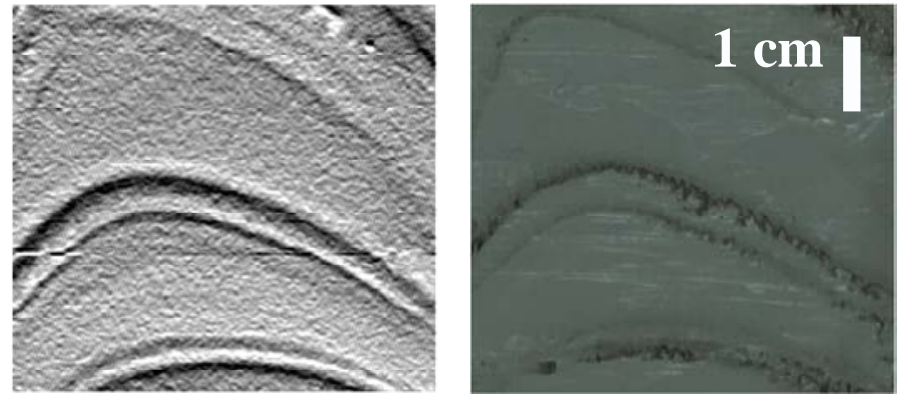

Turbidite facies 4 


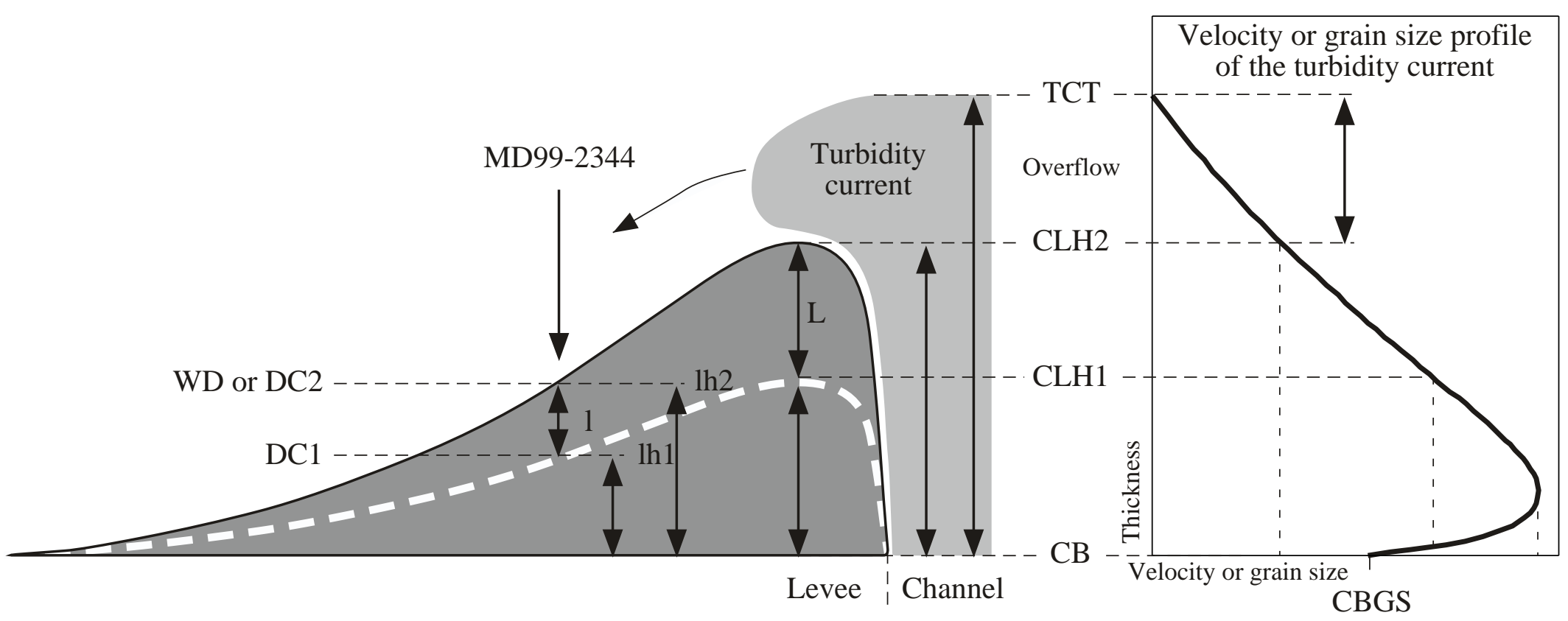




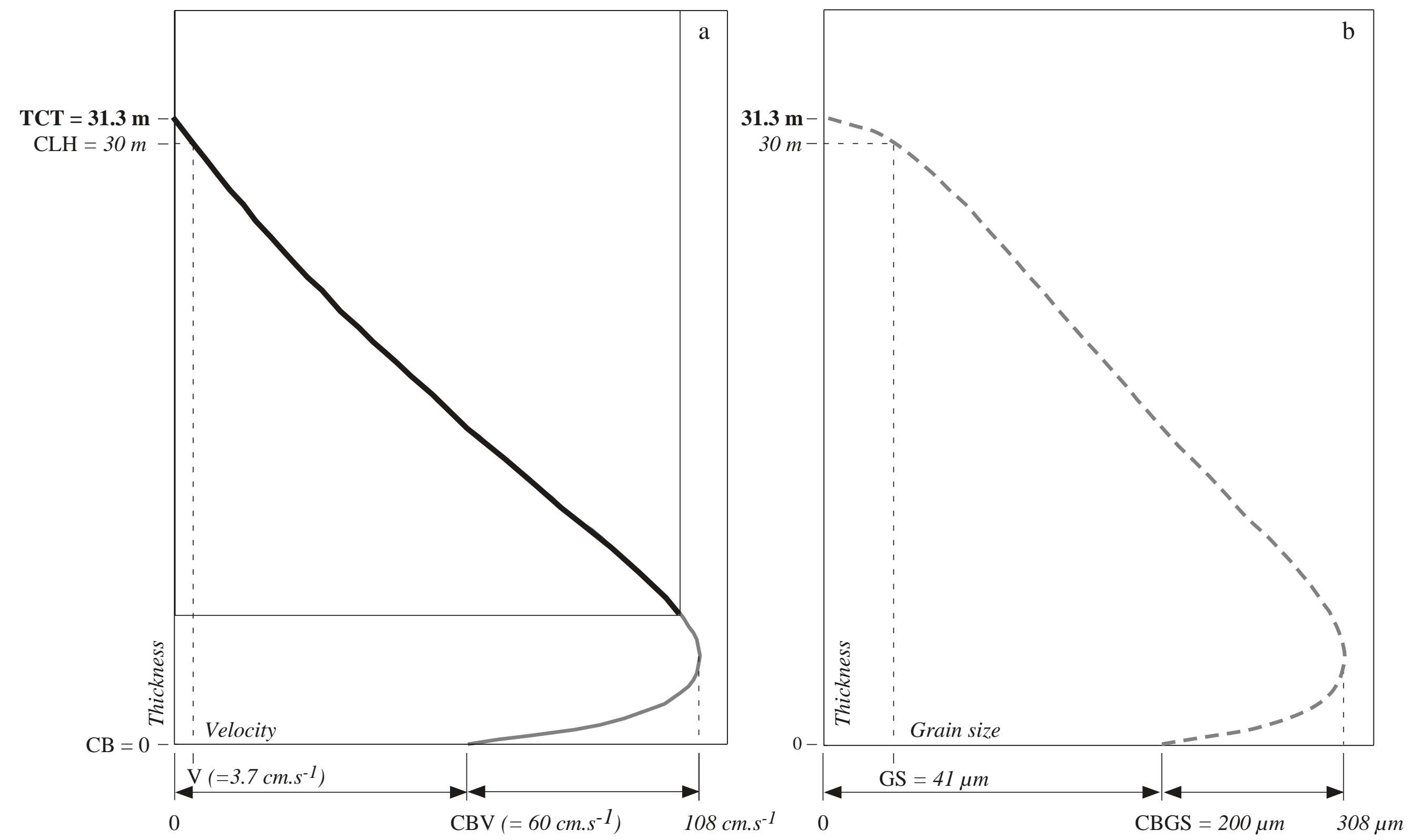



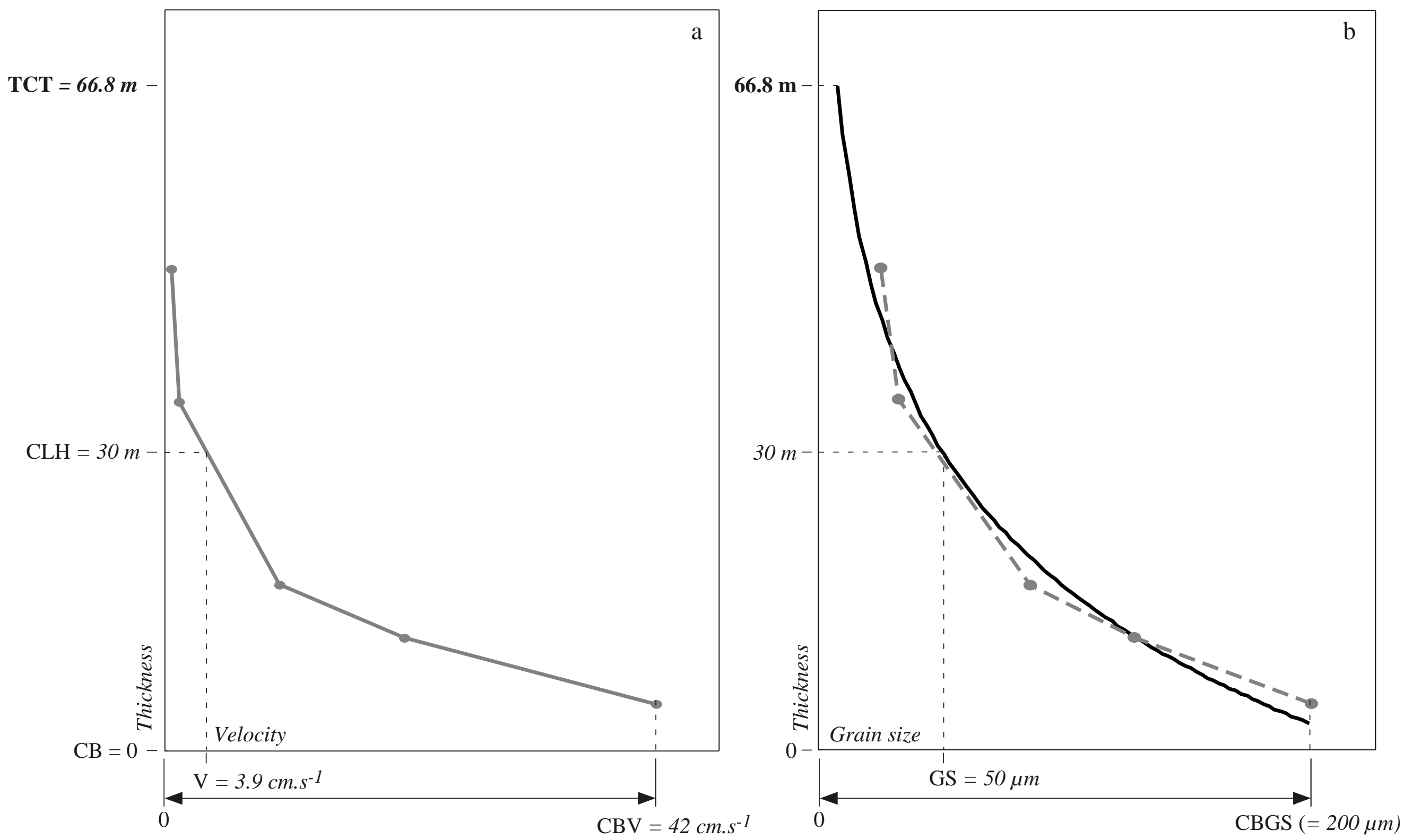

Dennielou et al., Figure 13 

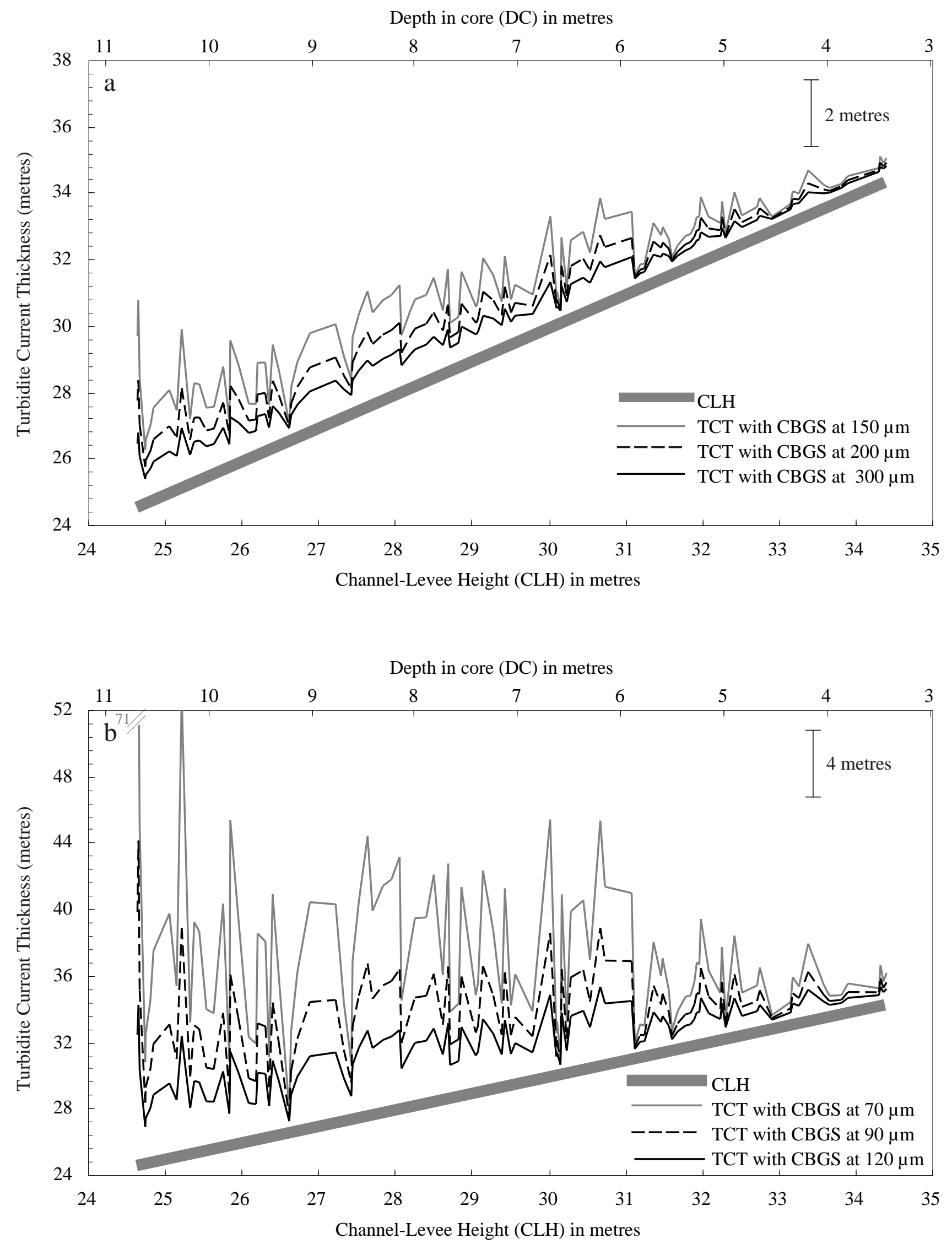

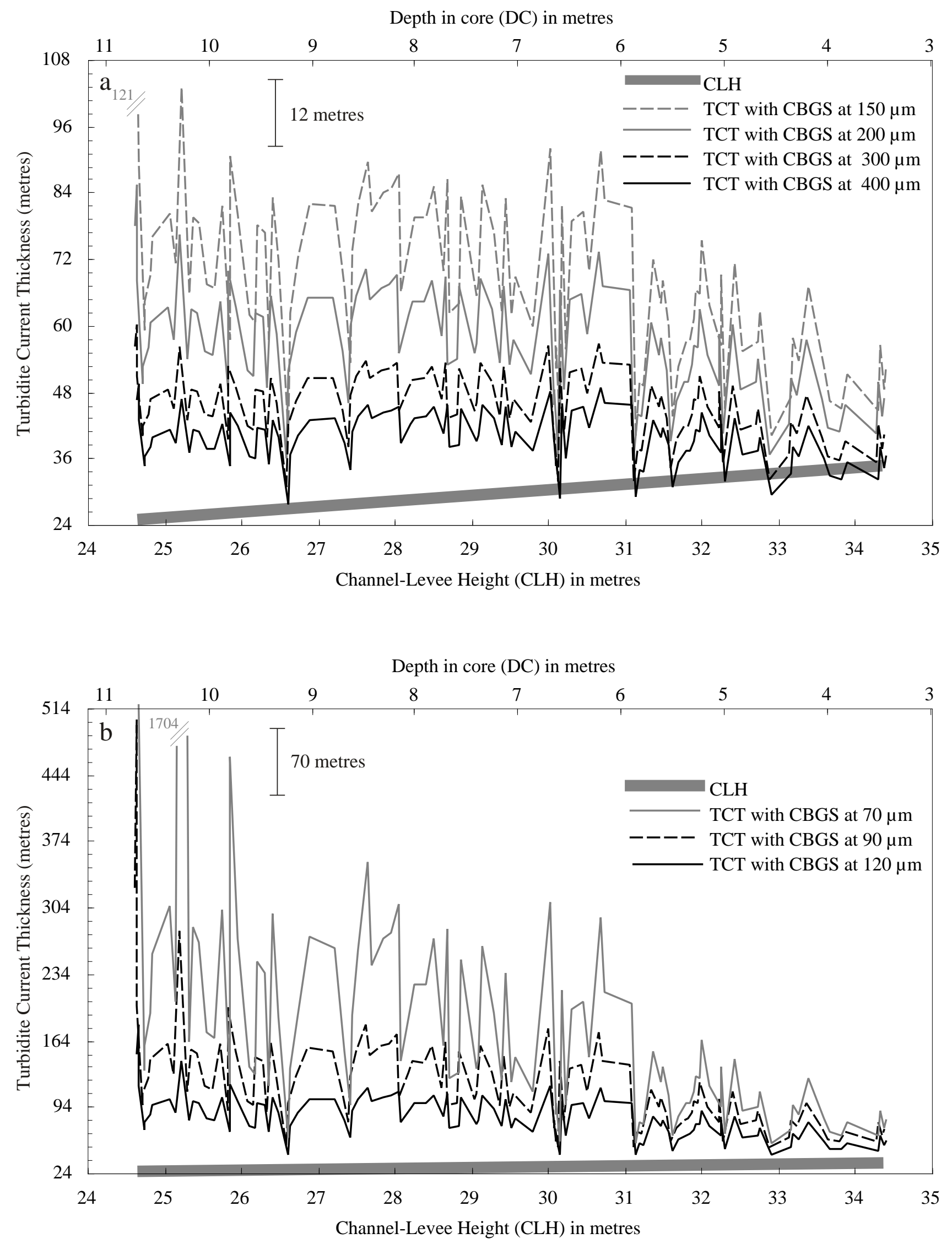


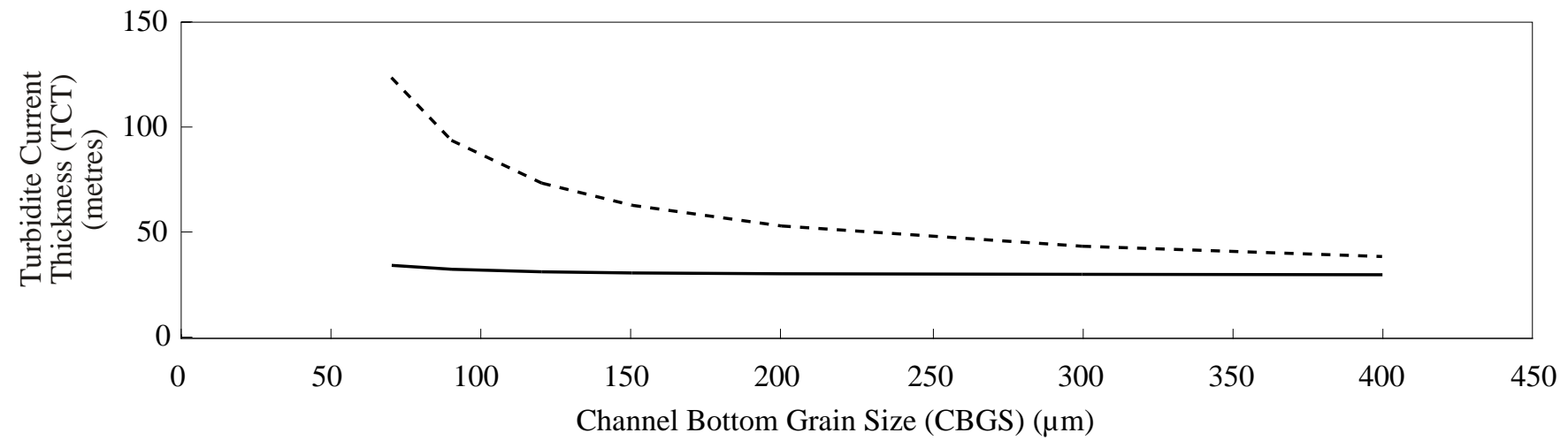

Dennielou et al., Figure 16 

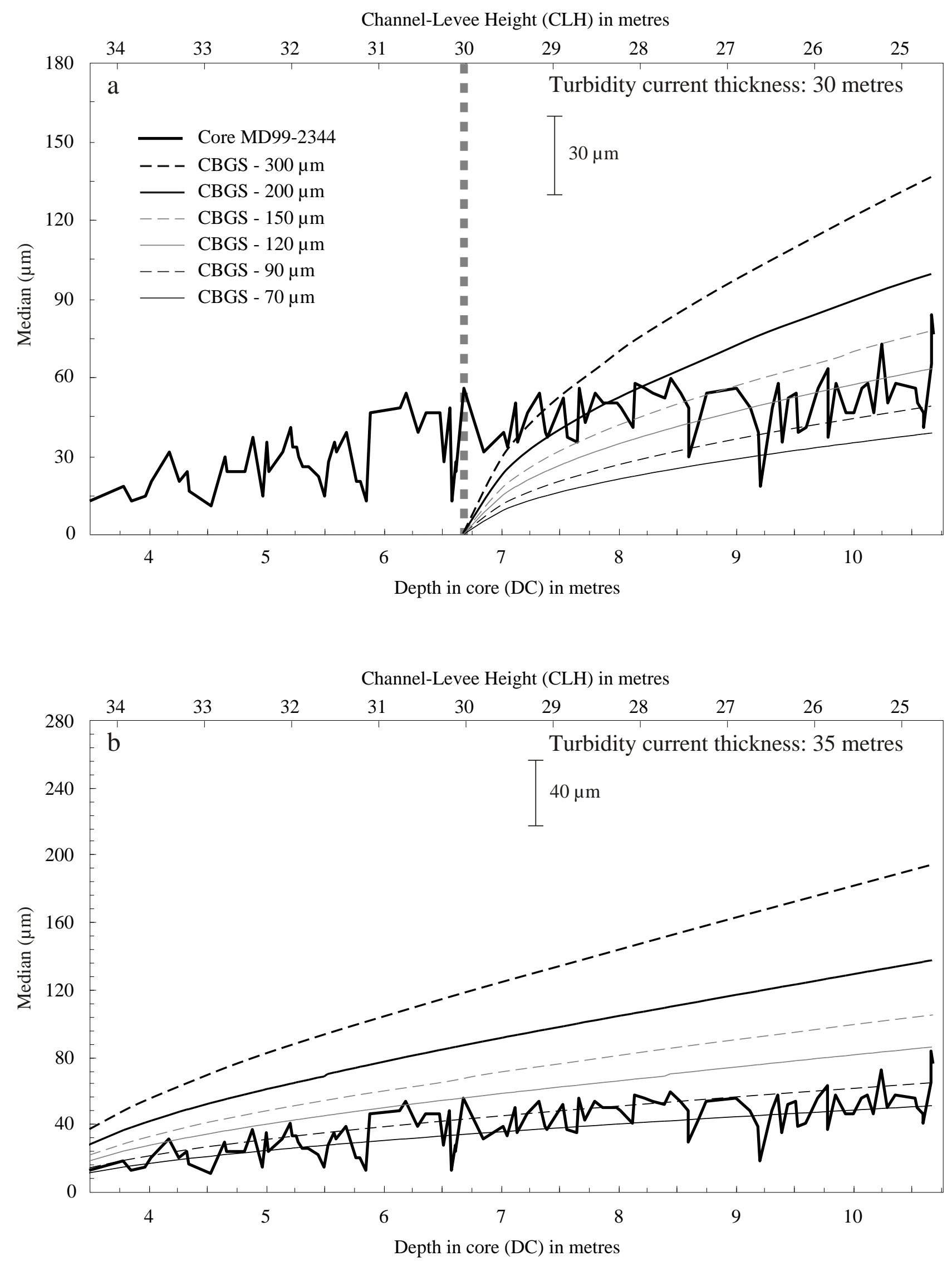

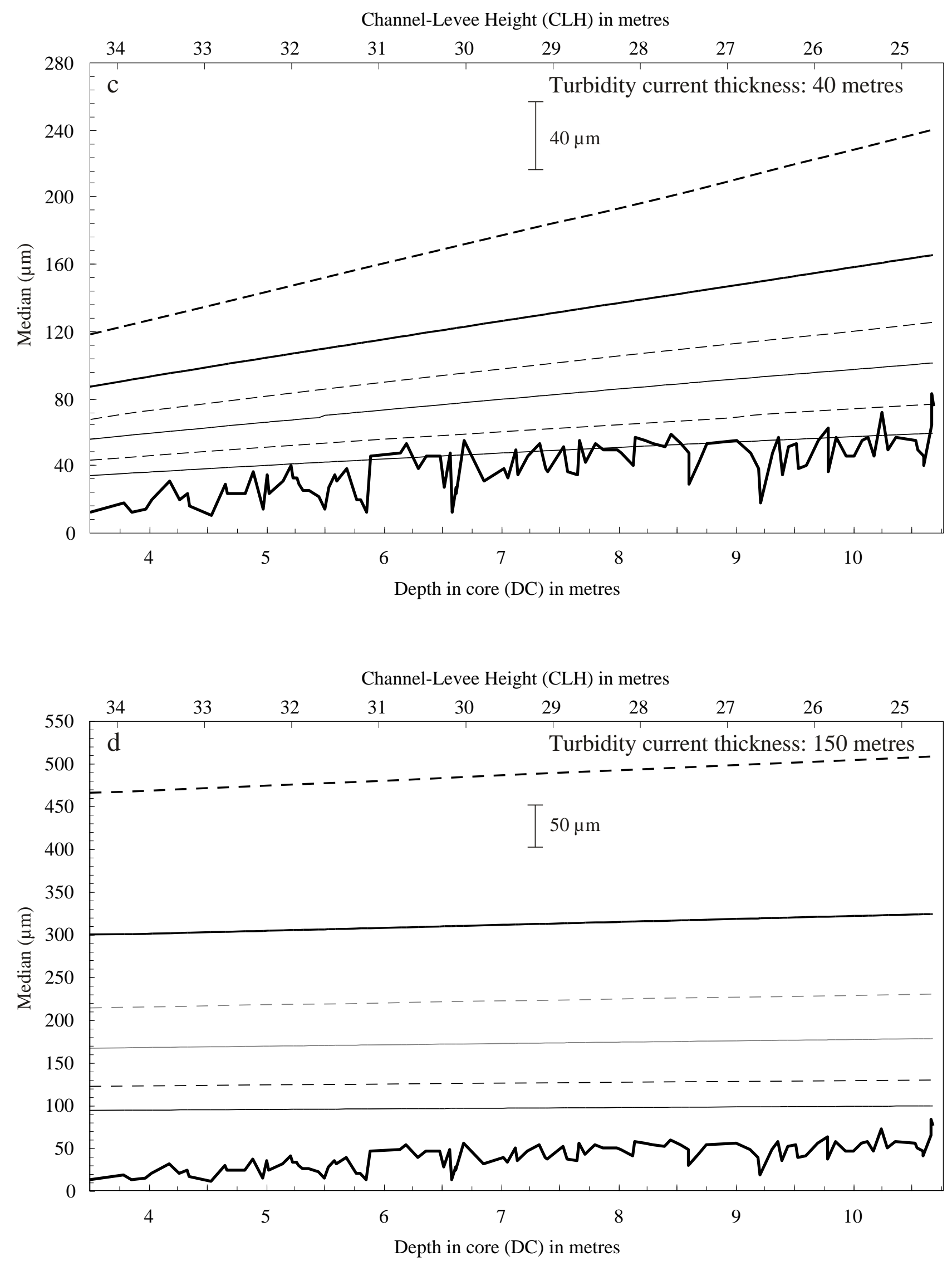

Dennielou et al., Figure 17 (end) 

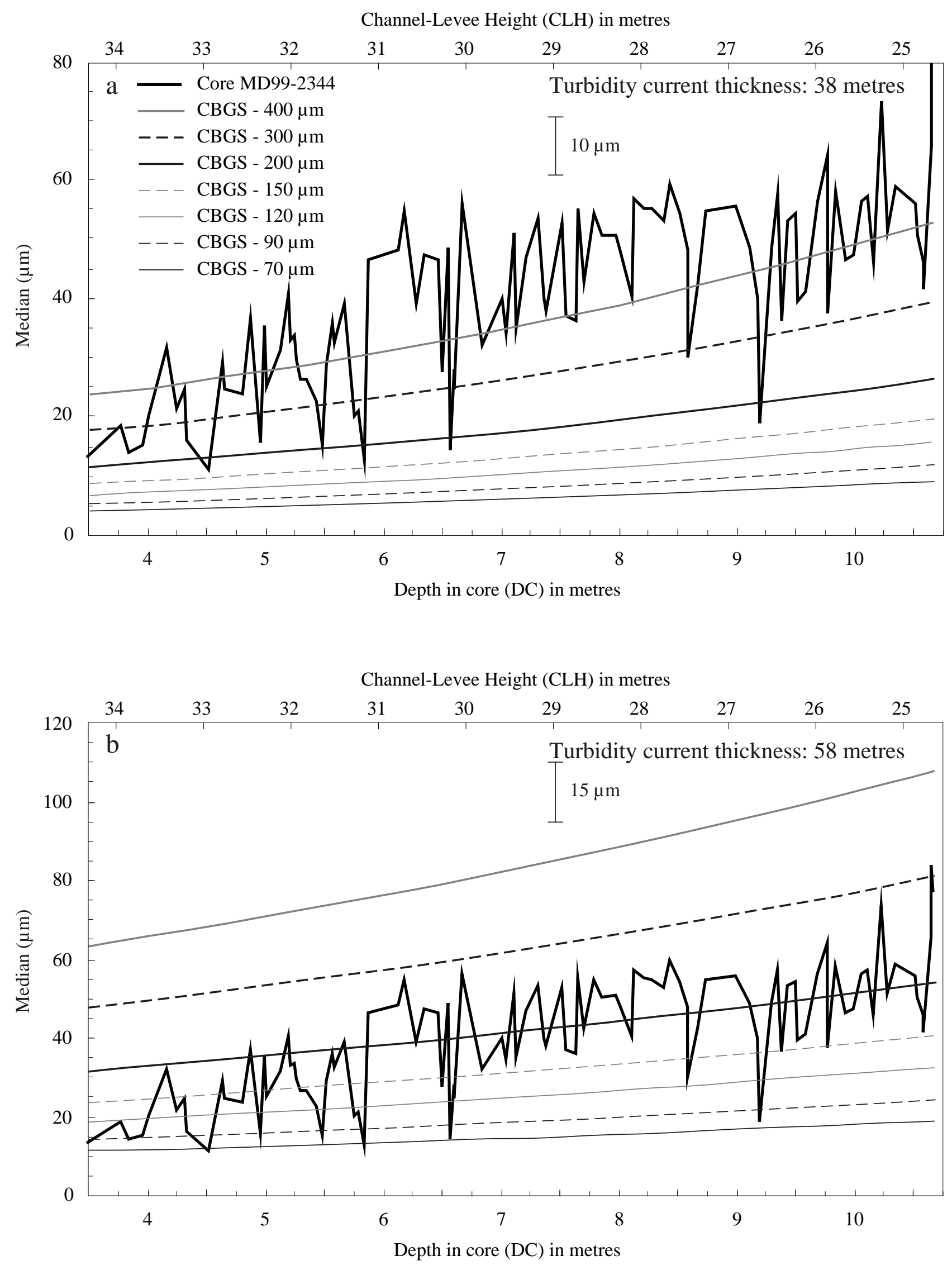

Dennielou et al., Figure 18 

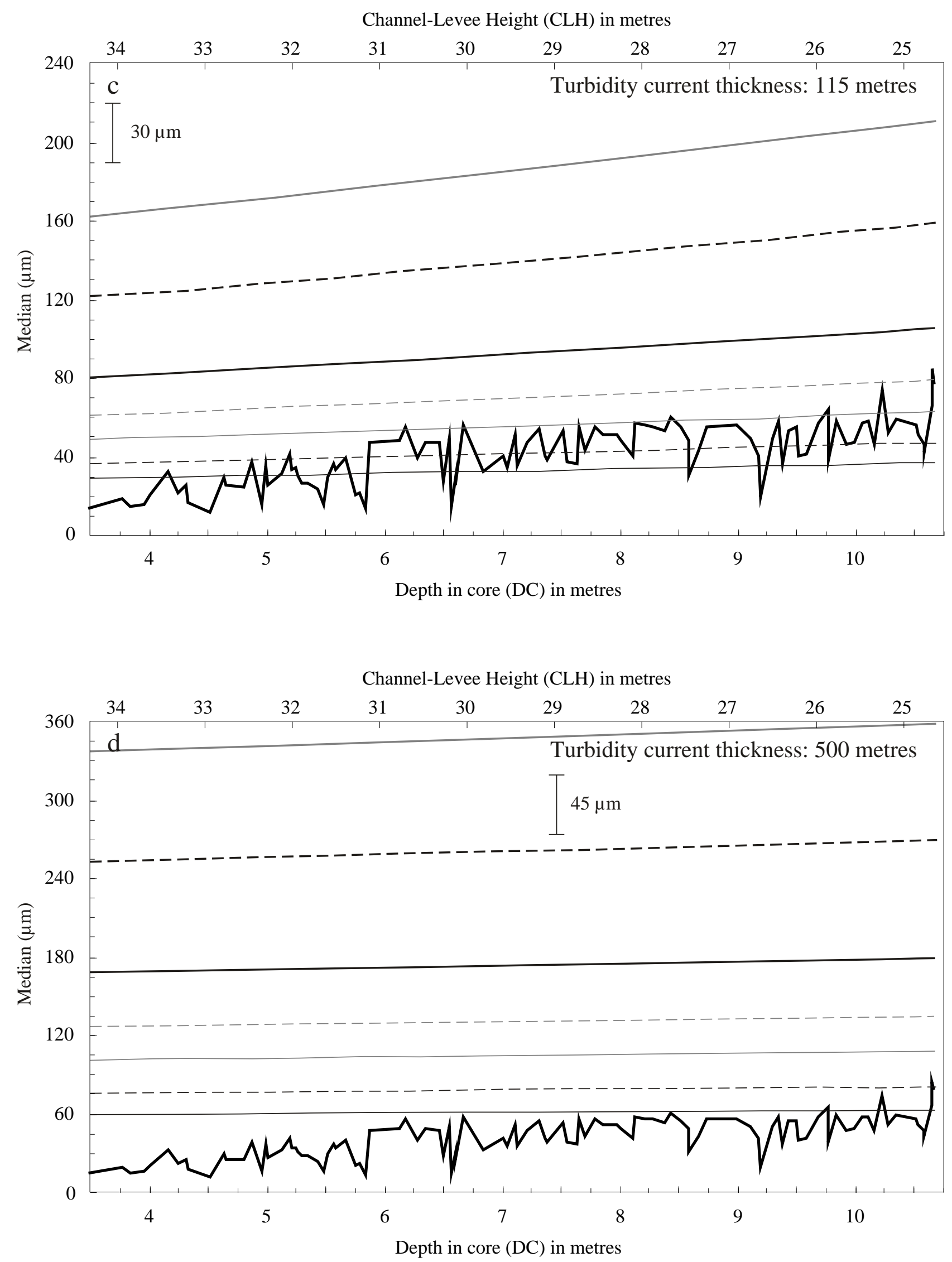

Dennielou et al., Figure 18 (end) 
a

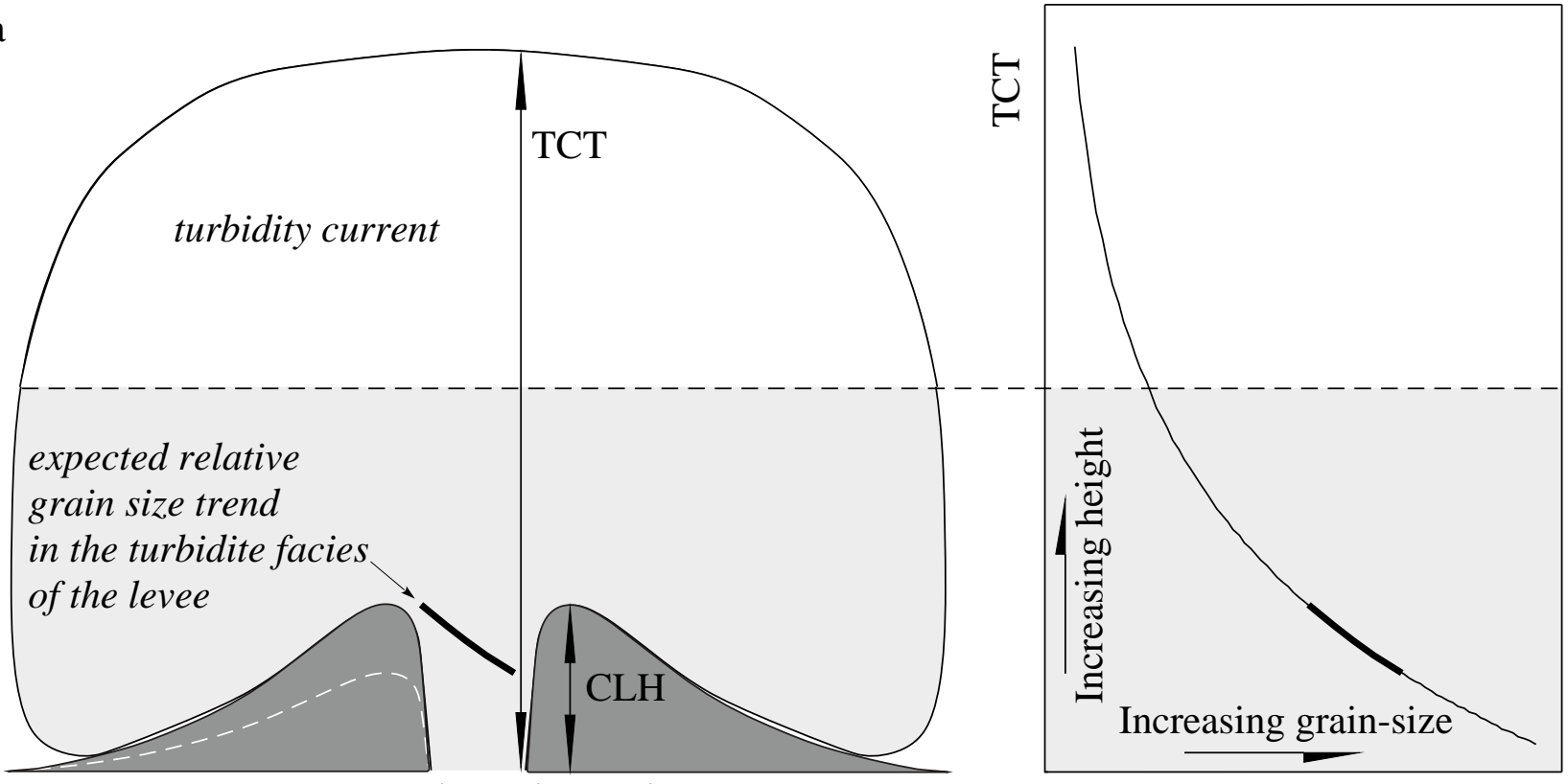

channel levee

GS

b

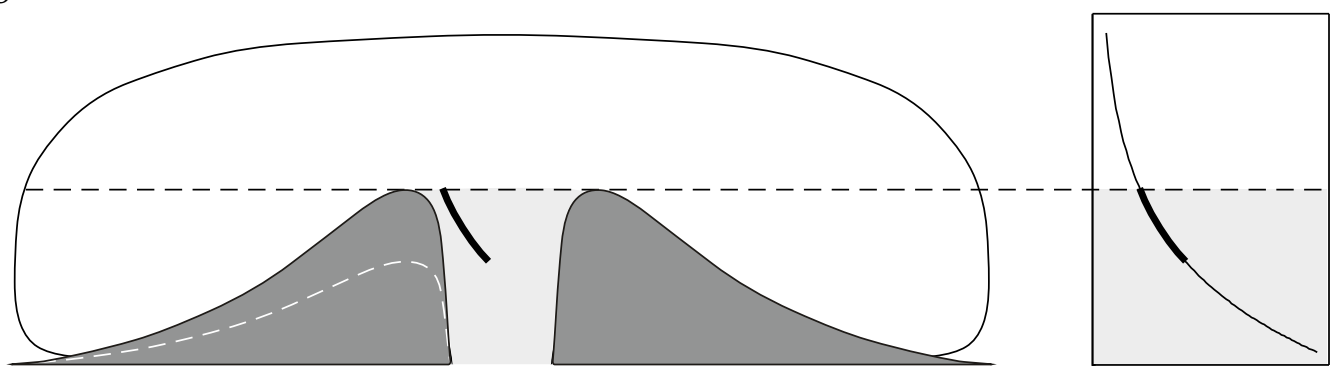

c

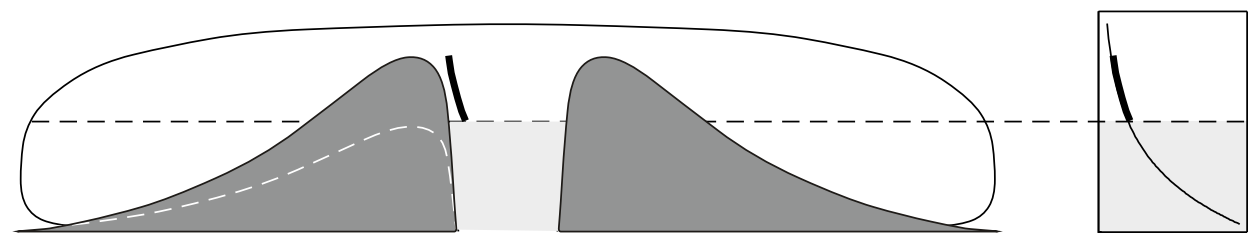

